\title{
Oligodendrocyte Response to Pathophysiological Conditions Triggered by Episode of Perinatal Hypoxia-Ischemia: Role of IGF-1 Secretion by Glial Cells
}

\author{
Justyna Janowska $^{1}$ • Justyna Gargas ${ }^{1}$ - Malgorzata Ziemka-Nalecz ${ }^{1} \cdot$ Teresa Zalewska $^{1}$ • Joanna Sypecka ${ }^{1}$ (D)
}

Received: 16 April 2020 / Accepted: 8 July 2020 / Published online: 21 July 2020

(C) The Author(s) 2020

\begin{abstract}
Differentiation of oligodendrocyte progenitors towards myelinating cells is influenced by a plethora of exogenous instructive signals. Insulin-like growth factor 1 (IGF-1) is one of the major factors regulating cell survival, proliferation, and maturation. Recently, there is an ever growing recognition concerning the role of autocrine/paracrine IGF-1 signaling in brain development and metabolism. Since oligodendrocyte functioning is altered after the neonatal hypoxic-ischemic (HI) insult, a question arises if the injury exerts any influence on the IGF-1 secreted by neural cells and how possibly the change in IGF-1 concentration affects oligodendrocyte growth. To quantify the secretory activity of neonatal glial cells, the step-wise approach by sequentially using the in vivo, ex vivo, and in vitro models of perinatal asphyxia was applied. A comparison of the results of in vivo and ex vivo studies allowed evaluating the role of autocrine/paracrine IGF-1 signaling. Accordingly, astroglia were indicated to be the main local source of IGF-1 in the developing brain, and the factor secretion was shown to be significantly upregulated during the first $24 \mathrm{~h}$ after the hypoxic-ischemic insult. And conversely, the IGF-1 amounts released by oligodendrocytes and microglia significantly decreased. A morphometric examination of oligodendrocyte differentiation by means of the Sholl analysis showed that the treatment with low IGF-1 doses markedly improved the branching of oligodendroglial cell processes and, in this way, promoted their differentiation. The changes in the IGF-1 amounts in the nervous tissue after HI might contribute to the resulting white matter disorders, observed in newborn children who experienced perinatal asphyxia. Pharmacological modulation of IGF-1 secretion by neural cells could be reasonable solution in studies aimed at searching for therapies alleviating the consequences of perinatal asphyxia.
\end{abstract}

Keywords Glial cells $\cdot$ Oligodendrocyte maturation $\cdot$ Astrocytes $\cdot$ Microglia $\cdot$ Neural development $\cdot$ Perinatal asphyxia $\cdot$ Neonatal hypoxia-ischemia $\cdot$ IGF-1 secretion $\cdot$ Autocrine/paracrine effect $\cdot$ Sholl analysis of cell branching

\section{Introduction}

To acquire the ability to myelinate the central nervous system (CNS), oligodendrocyte progenitor cells (OPCs, so called NG2-glia) have to undergo a multistage differentiation process, which is guided by a plethora of extracellular instructive signals. Some of them are known to guide OPCs migration, like for instance the activity of metalloproteinases which help to reorganize the extracellular matrix and facilitate cell

Joanna Sypecka jsypecka@imdik.pan.pl

1 NeuroRepair Department, Mossakowski Medical Research Centre, Polish Academy of Sciences, 5, A. Pawinskiego Str., 02-106 Warsaw, Poland trafficking, the gradient of PDGF-AA concentration in the local microenvironment, as well as the presence of either chemoattractants or chemorepellents associated with normal or pathophysiological conditions. Other signaling molecules are known to be engaged in cell survival, proliferation, and initiation of myelin gene expression [1]. Finally, the multibranched mature oligodendrocytes are able to extent their unique, specialized cell processes and to wrap them around axonal segments forming multilamellar, tightly compacted myelin sheaths [2-4].

One of the major factors shown to regulate oligodendrocyte functions is the insulin-like growth factor-1 (IGF-1), distributed throughout the body by circulating blood, but also secreted in situ in the nervous tissue [5]. This small, a 7.64-kDa peptide shares many similarities with insulin, including high 
sequence analogy and common signal transduction pathways. Accordingly, the IGF-1 acts through the canonical extracellular-regulated kinase (ERK) and phosphatidylinositol-3 kinase (PI3K)-Akt pathways, as well as through the JAK/STAT signaling cascade [6-10]. This growth factor is thought to be essential for normal brain development [11], by promoting neurogenesis, elongation of neuronal projections, dendritic arborization, and synaptogenesis [12-16]. In the nervous tissue, IGF-1 has been shown to serve also as a neuroprotectant, promoting neuronal survival, and proliferation [17-21]. Thus, it is hypothesized that in certain pathophysiological conditions occurring in the CNS (like for instance stroke, infections, autoimmunological diseases, hypoxic-ischemic episodes), the availability of this factor and the sensitivity of cells to its influence in various brain regions might be one of discriminative factors between the onset of neurodegenerative disorders and capability to overcome the local tissue crisis [22-26]. Accordingly, alterations in the IGF-1 level are supposed to be associated with the development of white matter diseases, resulting from myelin deficiency or malformation and subsequent white matter disorganization. And indeed, a growing list of evidence indicates that the IGF-1 plays an important role in controlling oligodendroglial functions, including promotion of developmental myelinogenesis [27]. Although the alterations in the IGF-1 concentration are thought to be associated with the fatal consequences of white matter disorders developing as a result of hypoxic-ischemic insult experienced by newborn children [28], the exact mechanism of pathogenesis remains still largely unknown.

Likewise, IGF-1 is supposed to be involved also in subsequent stages of oligogliogenesis and myelinogenesis. Likewise, it has been shown to stimulate the glial commitment of neural stem cells [29-31], to enhance rate of OPC proliferation [32-37], to promote their survival [38], and to direct their migration by activation of integrin-mediated intracellular signaling [39]. During the middle stages of oligodendrocyte development, IGF-1 regulates protein synthesis through the $\mathrm{PI} 3 \mathrm{~K} / \mathrm{mTOR} / \mathrm{Akt}$ and MEK/ERK pathways contributing to the progress in differentiation process [40-43]. Finally, this growth factor is engaged in initiation and coordination of myelinogenesis, as well as has been shown to promote remyelination [27, 44-48]. Taking into consideration its well established role in the neurogenesis and brain development $[49,50]$, maintaining the physiological level of IGF-1 seems to be crucial for local tissue homeostasis and, thus, for proper CNS development and functioning.

To address this issue, a study investigating the impact of temporal hypoxia-ischemia on IGF-1 secretion by particular subpopulations of CNS glia was designed, based on the in vitro (glial primary cell monocultures), ex vivo (hippocampal organotypic slice culture), and in vivo (rat model of perinatal asphyxia) experiments (Fig. 1). This approach allowed us to determine the IGF-1 quantities after perinatal asphyxic insult in vivo and to take a closer look at its secretion by the specialized glial cells in vitro. We hypothesized that potential alterations in the level of centrally distributed IGF-1, triggered by neonatal hypoxia-ischemia might exert an acute effect on oligodendroglial cells and aimed at evaluating a role of paracrine/autocrine IGF-1 signaling in neonatal brains. Thus, the obtained results allowed us to speculate about contribution of the glial cells to the pathogenesis of perinatal asphyxia and indicate potential therapeutic strategies.

\section{Materials and Methods}

\section{Rat Model of Neonatal Hypoxia-Ischemia}

To evoke the hypoxic-ischemic (HI) insult in animal model of perinatal asphyxia, Wistar rat pups $(n=48)$ of both sexes $(12$ $15 \mathrm{~g}$ body weight) were anaesthetized with isoflurane ( $4 \%$ for induction of anesthesia and $2 \%$ for anesthesia maintenance) on 7 postnatal day (P7). The procedure, approved by IV Local Ethics Committee on Animal Care and Use, was based on the dissection of the left common carotid artery, which was either exposed (sham-operated animals, $n=20$ ) or cut between the double ligatures of silk sutures $(n=28)$. After treating the resulting wound with lignocaine, animals were allowed to recover for $60 \mathrm{~min}$ in their home cages. Hypoxic conditions were achieved by exposing the animals to $7.5 \%$ oxygen in nitrogen for $60 \mathrm{~min}$ in a hypoxic chamber heated to $35^{\circ} \mathrm{C}$. Consequently, the hemisphere ipsilateral to the carotid ligation experienced the ischemic-hypoxic injury.

\section{Ex Vivo Culture of Organotypic Hippocampal Slices}

The hippocampi for preparation of $400-\mu \mathrm{m}$ thick organotypic slices with the preserved tissue organization were isolated from the brains of 7-day-old Wistar rats $(n=18)$, according to the protocol described previously [51]. The procedure was approved by the IV Local Ethics Committee on Animal Care and Use (Ministry of Science and Higher Education). The slices, obtained by cutting the chilled hippocampi by use of a McIlwain apparatus, were placed on Millicell-CM (Millipore) membranes and cultured initially in DMEM medium (Gibco) containing the following supplements: $25 \%$ horse serum (Gibco), 25\% HBSS (Gibco), 2 mmol/1 L glucose (Sigma), 5-mg/ml HEPES (Gibco), B27 supplement (Gibco), and an antibacterial-antimycotic solution (Sigma). On the day following establishing the ex vivo culture, the serum concentration in the culture medium was gradually decreased and therefore from the 5 day in vitro (DIV) onwards, the slices were kept for the following 7 days in serum-free media and in normoxic gas conditions $\left(5 \% \mathrm{O}_{2}, 5 \% \mathrm{CO}_{2}\right)$. 
Fig. 1 A schematic diagram of a step-wise approach aimed at determining the role of the IGF-1 released in situ by glial cells inhabiting the CNS

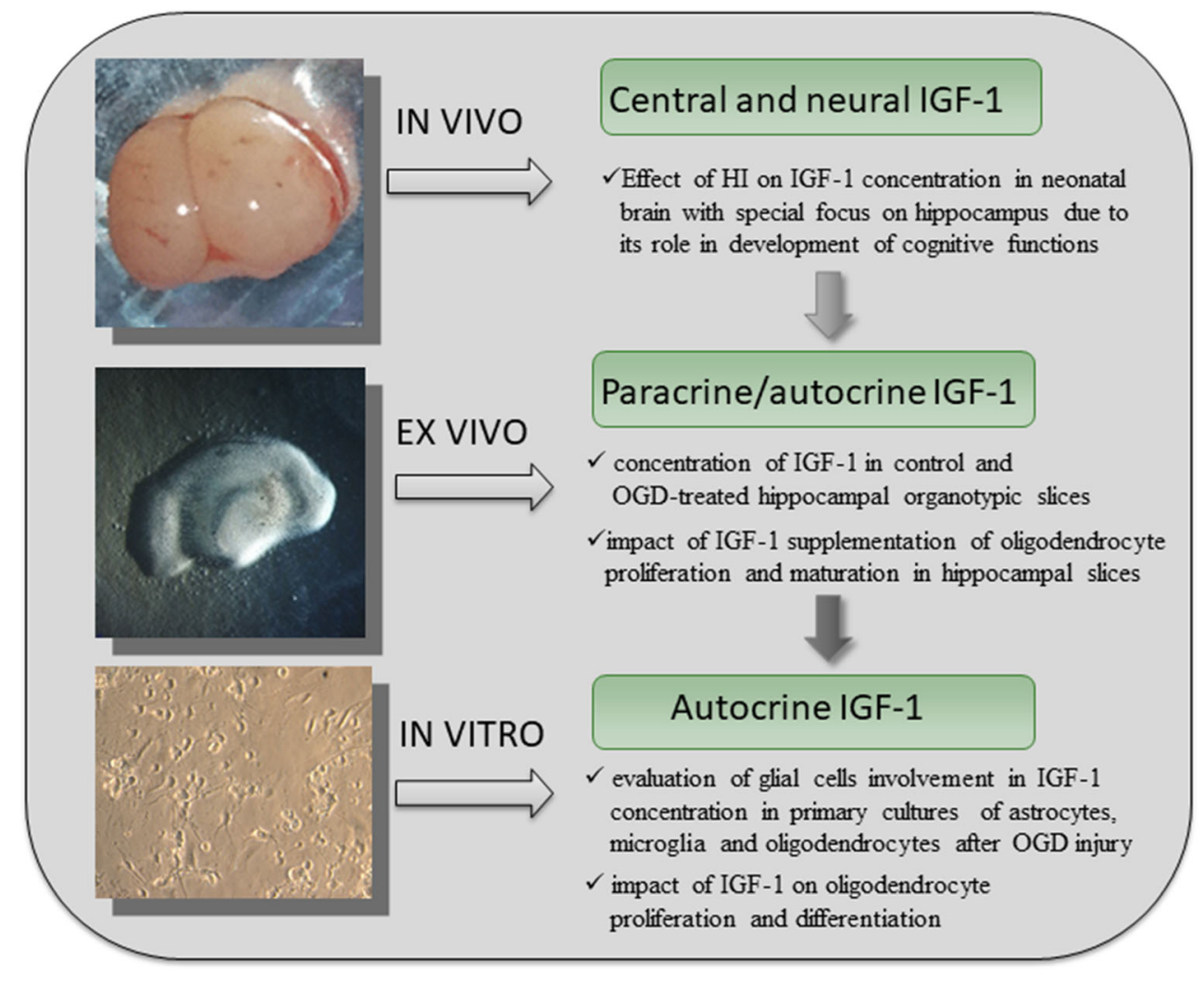

\section{Primary In Vitro Cultures of Rat Glial Cells}

Initial primary culture comprising glial cells were isolated from 2-day-old Wistar rats bred in the Animal Care Facility (the Mossakowski Medical Research Centre). The protocol of the nervous tissue acquisition, approved by the Local Ethics Committee on Animal Care and Use, was described in detail elsewhere [52]. Briefly, the neonatal animals $(n=36)$ were put into deep hypothermia, cerebral hemispheres were isolated and mechanically dispersed in Dulbecco's Modified Eagle's Medium (DMEM) (Gibco supplemented with $10 \%$ fetal bovine serum (FBS, Gibco) and 1\% antibiotic-antimycotic solution (Sigma, by means of a Pasteur pipette and a $1.2-\mathrm{mm}$ Luer-Lock needle. Cells were then filtered through a $40.0-\mu \mathrm{m}$ pore cell strainer (pluriSelect and seeded into $75-\mathrm{cm}^{2}$ culture flasks (NUNC). After being cultured for the following 1113 days, the subsequent fractions of glial cells were separated by gentle detaching by use of a horizontal orbital shaker (Biosan). The first detached fraction obtained due to 1-h long shaking at $160 \mathrm{rpm}$ corresponded to the microglial cells which were immediately plated at density of $4 \times 10^{4} / \mathrm{cm}^{2}$ at 6 -well plates coated with poly-L-lysine (Sigma). Shaking the remaining mixed glial culture for additional $15-20 \mathrm{~h}$ allowed the isolation of the OPCs, which were plated at density of $1.5 \times$ $10^{4} / \mathrm{cm}^{2}$. Next, the astroglial fraction was detached by mild trypsinization $\left(5 \mathrm{~min}\right.$. at $37^{\circ} \mathrm{C}$ ) and after being washed with PBS, the astrocytes were seeded at the same density as microglial cells. The resulting glial monocultures (i.e., primary cultures of microglia, oligodendrocyte progenitors, and astrocytes, respectively) were grown in a serum-free medium in atmosphere containing $5 \% \mathrm{O}_{2}$ and $5 \% \mathrm{CO}_{2}$, corresponding to the physiological normoxia. Homogeneity of the glial monocultures were checked every time with application of the lineage-specific markers and estimated for not less than 98.5\% for each of the particular subpopulation of glial cells.

\section{Temporal Oxygen-Glucose Deprivation as an In Vitro Model of Perinatal Asphyxia}

To mimic hypoxic-ischemic insult associated with perinatal asphyxia, organotypic hippocampal slices, as well as all glial monocultures were subjected to a temporal limitation of oxygen and glucose supply (OGD: oxygen and glucose deprivation). The procedure was performed on primary cultures $24 \mathrm{~h}$ after plating microglia and astrocytes, $4 \mathrm{~h}$ after plating OPCs and on 7 DIV in ex vivo cultures of the nervous tissue slices. To retain the buffer osmotic concentration unchanged, the glucose was replaced with $10-\mathrm{mM}$ mannitol. In order to eliminate oxygen, the Ringer solution used to perform OGD procedure was saturated with $95 \% \mathrm{~N}_{2}$ and $5 \% \mathrm{CO}_{2}$. Duration of OGD in oxygen-free chamber was established for $50 \mathrm{~min}$. Immediately after the OGD, the cultures were returned to their standard conditions. 


\section{Quantitative Determination of IGF-1 Content in Primary Cell Cultures, Hippocampal Slices and Brain Hemispheres}

IGF-1 quantities were measured in the samples collected from all of the in vivo, ex vivo, and in vitro models of perinatal asphyxia (Fig. 1). Accordingly, rat brains subjected to neonatal hypoxic-ischemic injury were extracted either on $1,3,7$, or 14 day postinjury (PI) and divided into ipsilateral (to the insult) and contralateral hemispheres. Thus the applied animal model allowed us to track the impact of both the reduced blood flow and hypoxia on the nerve tissue in ipsilateral hemisphere (ipsi) and the impact of hypoxia in contralateral brain hemisphere (contra). Amounts of IGF-1 were measured in tissue lysates of cerebral hemispheres and hippocampus separately, from both the injured and the sham-operated animals. For the purpose of ex vivo studies, organotypic hippocampal slices were collected 1, 3, 5, and 7 days after OGD. Likewise, supernatants conditioned by in vitro monocultures of glial cells were collected at time points corresponding to 1 day and 3 days after OGD. For the quantification of the intracellular IGF-1, oligodendrocytes were lysed either $1 \mathrm{~h}, 1$ day, or 3 days after OGD. Homogenates of the collected tissue and cell samples were prepared with the application of CelLytic solution (Sigma), supplemented with Protease Inhibitor Cocktail (1:100, Sigma). Measurements of the total protein concentrations in the lysates obtained from brain and slices were performed by means of DC protein assay (Bio-Rad), based on the standard Lowry method. For precisely measuring the lower protein concentrations (in culture supernatants and in lysates of cell cultures), Bradford Reagent (Sigma) was used. To precisely quantify the IGF-1 amounts, the ultrasensitive sandwich ELISA (enzyme-linked immunosorbent assay) was used according to the manufacturer's recommendations (Thermo Fisher Scientific). The intensity of the resulting colorimetric reaction was measured at $450-\mathrm{nm}$ wave length with use of the spectrophotometric plate reader Fluorostar Omega (BMG LabTech).

\section{Testing the Influence of IGF-1 on Cell In Vitro and Ex Vivo Cultures}

To evaluate the influence of IGF-1 on survival, proliferation, and maturation of rat oligodendrocytes, different concentrations (varying from 10 to $50 \mathrm{ng} / \mathrm{ml}$ ) of this compound (Thermo Fisher Scientific) were added to the culture medium of oligodendrocytes and the organotypic hippocampal slices immediately after OGD for the following 5 days. In another experimental variant, the endogenous IGF-1 released by glial cells to the culture medium was neutralized by addition of the extensive amounts of either antilGF-1 (1:1000; MerckMillipore) or antiIGF-1R (receptor) antibodies (1:400; Abcam). The effectiveness of IGF-1R or IGF-1 neutralization was verified by application of ELISA method. Accordingly, the culture media were collected and assayed for testing the possible IGF-1 presence. Standard culture media (with no supplements), conditioned by control primary glial monocultures, served as a positive control. Then the cells and slices were fixed with $4 \%$ paraformaldehyde (PFA) in PBS for $20 \mathrm{~min}$ and $40 \mathrm{~min}$, respectively, rinsed three times with PBS and subjected to immunostaining with the selected antibodies.

\section{Immunostaining of Differentiating Cells}

In order to use immunostaining techniques, the glial monocultures were fixed 5 days after OGD, while hippocampal slices were fixed 7 days after the procedure. To verify the homogeneity of glial cell cultures, cells were labeled with the selected lineage-specific antibodies, i.e., with antiIBA1 (1:200, Abcam) to distinguish microglia, antiCNPase (1:100, Merck Millipore) to detect oligodendrocytes, and antiGFAP (1:200, Merck Millipore) to visualize astrocytes. To evaluate differentiation of oligodendrocytes in the primary cultures and in the organotypic hippocampal slices, an additional immunolabeling was performed with oligodendroglial lineage-specific antibodies directed against NG2 (1:100, Chemicon) and Olig2 (1:500, Merck Millipore). Proliferating cells were visualized with antiKi67 antibody (1:100, Leica). Unspecific binding of antibodies was eliminated by incubating the fixed cells and the slices with $10 \%$ normal goat serum (Sigma) in PBS containing $0.1 \%$ (0.25\% for tissue slices) Triton X-100 (Serva) for $1 \mathrm{~h}$ at room temperature. All of the primary antibodies were applied overnight at $4{ }^{\circ} \mathrm{C}$. Secondary antibodies conjugated to fluorescent dyes, i.e., Alexa Fluor-488 and Alexa Fluor-546 (1:1000, Thermo Fisher Scientific) were used to label the immunostained cells. To visualize cell nuclei, Hoechst 33342 was applied during 15 min incubation. After immersing in the Fluoromount ${ }^{\mathrm{TM}}$ reagent (Sigma), the resulting slides were used for picture acquisition by means of the LSM 780/ ELYRA PS.1 superresolution confocal system (Carl Zeiss). The analyzed area of the hippocampal slice or cell culture corresponded to $0.386 \mathrm{~mm}^{2}$.

\section{Sholl Analysis of Cell Branching}

In order to evaluate a progress in the oligodendrocyte differentiation process, the branching of immunolabeled $\mathrm{NG}^{+}$cells was examined in hippocampal slices by application of Sholl morphometric analysis. Accordingly, the Z-stack microscopic images were collected, and the maximum intensity projections of individual cells were created to obtain detailed images of cells with all their branches on 2D plane. Subsequently, masks of cells were drawn with use of semiautomatic tracing method in the NeuronJ plugin to ImageJ software in order to generate 
the binary images of cell branching. A number of intersections of cell proccesses with consecutive concentric circles around the cell body were recorded, and a number of quantitative descriptors were calculated. All of the performed Sholl measurements were based on the following parameters: starting radius $-5 \mu \mathrm{m}$ and radius step $-1 \mu \mathrm{m}$.

\section{Statistical Analysis}

Biochemical measurements were done at least in triplicate, with two dilutions of the examined sample on each plate. The cells labeled by means of immunofluorescent techniques were counted on randomly selected 5-10 visual fields on each of at least five slides from each of the three experiments. A statistical analysis of the collected data was performed with the application of the GraphPad PRISM 8.0 software, selecting an one-way analysis of variance (ANOVA) followed by the Bonferroni's multiple comparison test as a tool to compare experimental groups. All the data were expressed as mean standard deviation. The calculated differences were recognized as the significant if: $* p<0.05, * * p<0.01$; $* * * p<0.001, * * * * p<0.0001$.

\section{Results}

\section{Influence of Hypoxic-Ischemic Insult on Endogenous IGF-1 Expression in Rat Neonatal Brains}

With aim of addressing the question about the potential impact of neonatal hypoxia-ischemia on the IGF-1 availability in the affected brains, the animal in vivo model of perinatal asphyxia was used (Fig. 1). Taking into consideration that the main neurological disabilities resulting from asphyxic injury in survived babies might be associated with the malfunctioning of hippocampus, this region was isolated and analyzed separately. Additionally, to evaluate the possible influence of $\mathrm{HI}$ on the hemisphere contralateral to the insult, the IGF-1 levels were measured separately in the both brain hemispheres (Fig. 2a) and the both hippocampi (Fig. 2b). Accordingly, as revealed by quantitative studies, just 1 day after the $\mathrm{HI}$ insult (1 PI), the amount of IGF-1 was significantly elevated in the ipsilateral hemisphere in comparison with the hemisphere contralateral in relation to the insult $(38.7 \% ; p<0.01)$ and to control brains $(24.9 \% ; p<0.05)$ (Fig. 2a). The examination of tissue lysates obtained from the brains collected 3, 7, and 14 after the injury did not revealed any statistically relevant differences between the injured and the control hemispheres $(p>0.05)$. This suggests that during the later post injury period, the amounts of IGF-1 decreased and stabilized at the physiological level. Interestingly, the highest endogenous level of IGF-1 in the neonatal brains was detected 7 days after the injury (which corresponds to P14) and was estimated at
$1143.00 \pm 119.37 \mathrm{pg}$ per $\mathrm{mg}$ of the total protein content. During the following week (7-14 PI), an approximate 3-fold decrease (to $357.94 \pm 35.74 \mathrm{pg} / \mathrm{mg}$ total protein content) was recorded in the samples derived from the control brains (Fig. 2a). While examining hippocampi, a 2-fold decrease in the IGF-1 level was observed between day 7 and 14 postinjury (from $752.53 \pm 221.73$ to $368.73 \pm 64.39 \mathrm{pg}$ IGF- $1 / \mathrm{mg}$ of total protein content) (Fig. 2b). Interestingly, the upregulation of the IGF-1 level $24 \mathrm{~h}$ after the HI insult was not observed in this brain region. However, IGF-1 quantification at different time-points postinjury indicates that the observed increase in its physiological amounts proceeds more slowly in the hippocampi affected by HI $(p<0.05$ for 1PI vs 3PI and $p>0.05$ for $3 \mathrm{PI}$ vs $7 \mathrm{PI})$ in comparison with controls $(p<0.0001$ for $1 \mathrm{PI}$ vs 3PI and $p<0.001$ in case of 3PI vs 7PI).

\section{Influence of Hypoxic-Ischemic Insult on Paracrine/Autocrine IGF-1 Release in Ex Vivo Cultures of Organotypic Hippocampal Slices}

To eliminate potential augmentation of centrally generated IGF-1 and delivered via brain-blood barrier (BBB) to the nervous tissue, the ex vivo cultures of organotypic hippocampal slices were used. This approach (presented in Fig. 1) allowed us to focus on the paracrine/autocrine effects of IGF-1 secreted in situ by neural cells. As revealed by the obtained data, the IGF-1 amounts in the hippocampal slices cultured up to 14 days (7 days before and 7 days after OGD) were similar to those determined in the hippocampi during the in vivo studies, pointing to the important role of neural cells as the endogenous source of this factor in hippocampal region (Fig. 3). Likewise, there was also no difference between the control and the OGD-treated tissue. The amount of IGF-1 in the samples collected 5 days and 7 days after the insult was below the lower limit of detection defined by the ELISA kit's manufacturer, suggesting decrease in IGF-1 secretion during following days of the ex vivo culture. Since cell differentiation and senescence is remarkably accelerated in the cultured tissue slices, this time-point seems to be relevant to the 7-14 PI period of the in vivo model.

\section{Effect of IGF-1 Supplementation on Oligodendroglial Proliferation in Hippocampal Slices}

To identify the proliferating cells within the nervous tissue of the hippocampal region, the antibody against Ki67 protein in the dividing cell nuclei together with markers specific for oligodendroglial lineage were used. First of all, the possible influence of various IGF-1 doses on oligodendrocyte progenitor cells was tested. As determined by quantitative biochemical methods, the IGF- 1 concentrations range between 0.5 and $1 \mathrm{ng}$ per mg of total protein content in the nervous tissue (Figs. 2 and 3). Since in the performed ex vivo study the cultures of 


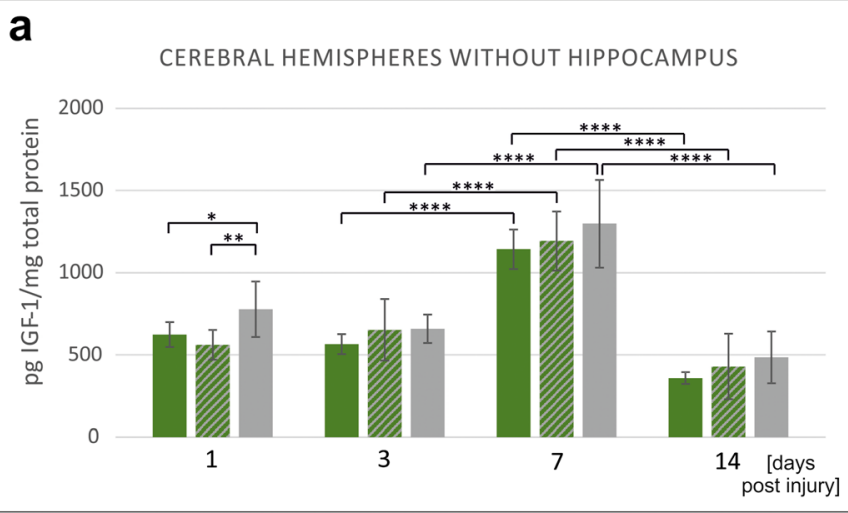

Fig. 2 IGF-1 level in rat brains at various time-points after hypoxicischemic insult applied to $\mathrm{P} 7 \mathrm{rat}$ pups, determined in: a Brain hemispheres (without hippocampus) and $\mathbf{b}$ Isolated hippocampal region. The plain green bars represent concentration of IGF-1 in brains of control animals, striped green bars represent hemispheres contralateral to the site of the injury (which became hypoxic due to the applied model) and the gray

hippocampal slices were supplemented with the exogenous IGF-1, the calculation of concentrations of the added compound were based on the manufacturer recommendations. Likewise, supplementing oligodendroglial or slice cultures with insulin (which is an analog of IGF-1) in concentration of $10 \mathrm{ng} / \mathrm{ml}$ (for instance in ITS supplement) was recommended for use to support oligodendroglial survival. Therefore, the tested IGF-1 doses were estimated for 10, 20, and $50 \mathrm{ng}$ per $\mathrm{ml}$ of culture media, and their influence on oligodendrocyte proliferation was verified by immunohistochemical analyses. The first interesting observation concerned the significantly ( $p$ $<0.01$ ) reduced number of dividing neural cells in hippocampal slices after OGD insult when compared with untreated controls (Fig. 4a, b). While added at the highest of the applied doses $(50 \mathrm{ng} / \mathrm{ml})$, the IGF-1 turned out to stimulate the process of cell proliferation in the control slices $(p<0.05)$ when compared with those untreated with IGF-1; however, the given

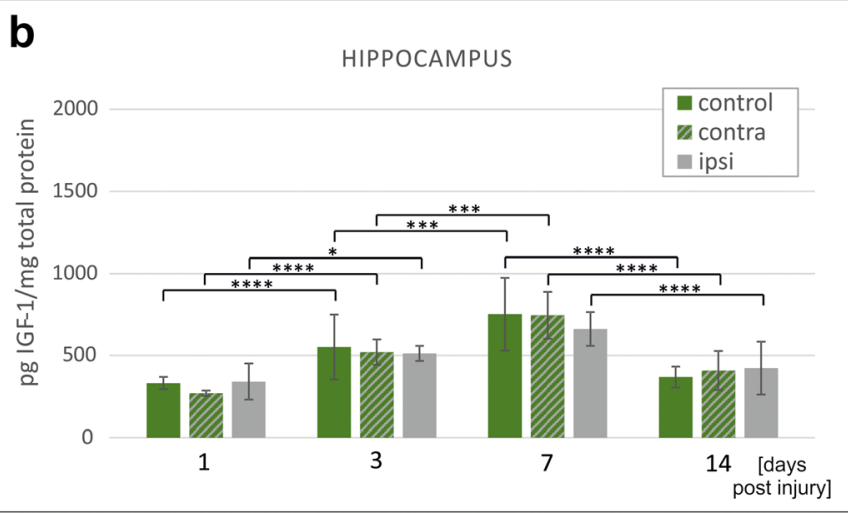

bars corresponds to the hemispheres ipsilateral to the site of injury (hypoxic-ischemic). Presented values are mean \pm standard deviation. The differences between the examined groups were marked as statistically significant if: significant* $p<0.05, * * p<0.01 ; * * * p<0.001, * * * * p<$ 0.0001

treatments seemed to be insufficient to promote cell division in the injured slices and to stimulate in this way process of neuroregeneration. Accordingly, the cell proliferation rate in OGD-injured slices cultured with addition of IGF-1 at concentration of $50 \mathrm{ng} / \mathrm{ml}$ was still significantly $(p<0.0001)$ lower than in control slices supplemented with the same IGF-1 dose (Fig. 4b).

Focusing the analyses on oligodendroglial progenitor cells, visualized by immunolabeling the membrane marker NG2, specific for the very early stage of oligodendrocyte differentiation process, also showed no significant effect on enhancing rate of cell proliferation after treatment with the applied doses of IGF-1. Interestingly, in spite of being temporarily deprived of oxygen and glucose, the number of proliferating OPCs in the entire fraction of the dividing neural cells remained markedly unchanged when examined 5 days after the insult. Accordingly, in the cultured hippocampal slices of rat
Fig. 3 IGF-1 quantification in the organotypic hippocampal slice culture 1 day and 3 days after oxygen-glucose deprivation. The concentrations of IGF-

1 determined by ELISA-based measurement were normalized versus total protein concentration in individual samples. Presented values are mean \pm standard deviation. $* p<0.05, * * p<0.01$

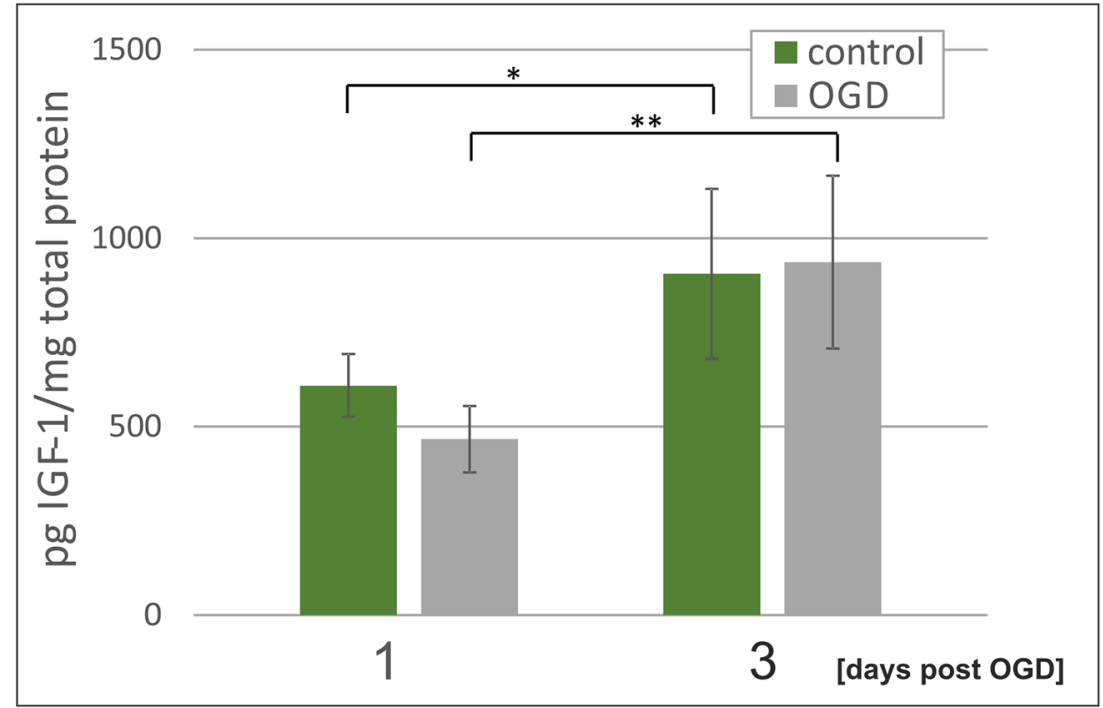



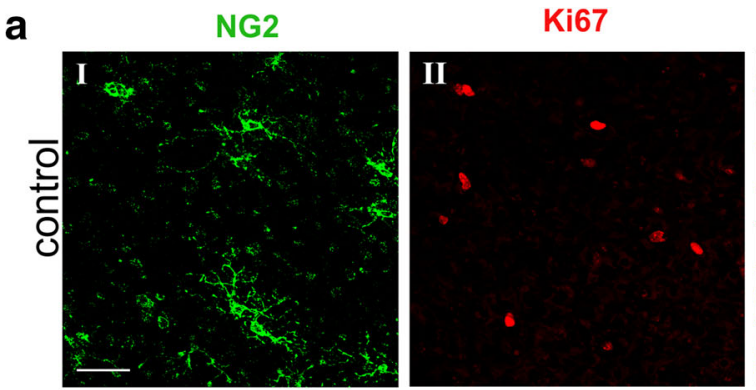

\section{NG2/Ki67/Hoechst}
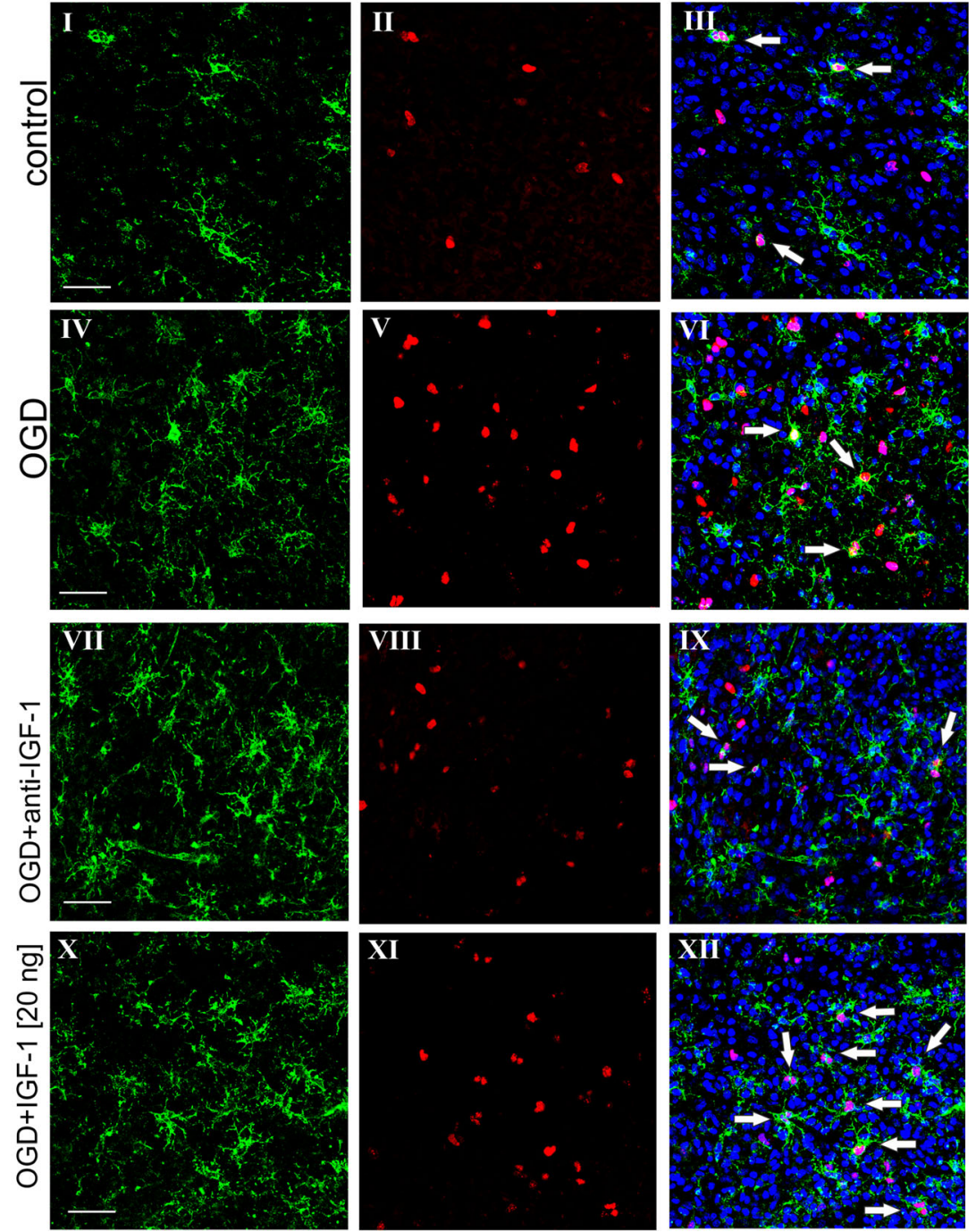

Fig. 4 Impact of oxygen and glucose deprivation followed by various treatments on proliferation of neural cells in the organotypic hippocampal slices, determined 5 days after the insult. a Immunohistochemical visualization of oligodendrocyte progenitors $\left(\mathrm{NG}^{+}\right.$, green) and proliferating, Ki67-positive cells (red). Cell nuclei are stained with Hoechst 33342 (blue). White arrows indicate dividing oligodendroglial progenitors $\left(\mathrm{NG}^{+} / \mathrm{Ki}^{+} 7^{+}\right.$. Microphotographs show hippocampal slices cultured in control conditions (I-III), affected by OGD (IV-VI) and after different treatments applied to OGD-injured cultures (VII-XII). Scale bar

neonatal brain, the dividing OPCs $\left(\mathrm{NG}^{+} / \mathrm{Ki}^{+} 7^{+}\right)$constituted $17.35 \pm 5.33 \%$ in controls and $12.55 \pm 2.11 \%$ after the OGD procedure of all the cycling cells (Fig. 4c). Subsequent examination of the results of the supplementing slice cultures with different IGF-1 doses indicated a general, significant decrease of the $\mathrm{NG}^{+} / \mathrm{Ki} 7^{+}$fraction in control slices, while after OGD this proportion significantly increased (Fig. 4d). This was further confirmed by examination of the number of dividing OPCs within total $\mathrm{NG}^{+}$fraction. Accordingly, the performed statistical analysis revealed that the stimulation of OPC proliferation by was most pronounced when IGF-1 was added at is equivalent of $50 \mu \mathrm{m}$. b Evaluation of the number of dividing neural cells after OGD and in response to various experimental treatment; $\mathbf{c}$ The number (expressed as the absolute values) of OPCs in various experimental conditions; $\mathbf{d}$ Calculation of the dividing OPC fraction in the entire pool of cycling cells in the nervous tissue of the hippocampal region. $\mathbf{e}$ Increase in number of proliferating OPCs in OGD-injured hippocampal slices treated with various IGF-1 doses. Presented values are mean \pm standard deviation; the results were considered as significant if: $* p<0.05, * * p<0.01 ; * * * p<0.001, * * * * p<0.0001$

concentrations of in the injured slices is the most pronounced in concentration of $10-20 \mathrm{ng} / \mathrm{mg}(p<0.01)$ (Fig. 4e). The obtained results showed that IGF-1 specifically increases proliferation rate of oligodendroglial precursors after OGD injury.

The subsequent examination of Olig2 immunolabeling, an oligodendroglial lineage-specific transcription factor expressed during both the cell commitment and differentiation, indicated however that the injury stimulated the oligodendrocytes to propagate (Fig. 5a, b), causing a $67.3 \%$ increase in the number of Olig $2^{+} / \mathrm{Ki} 67^{+}$cells when the slices 

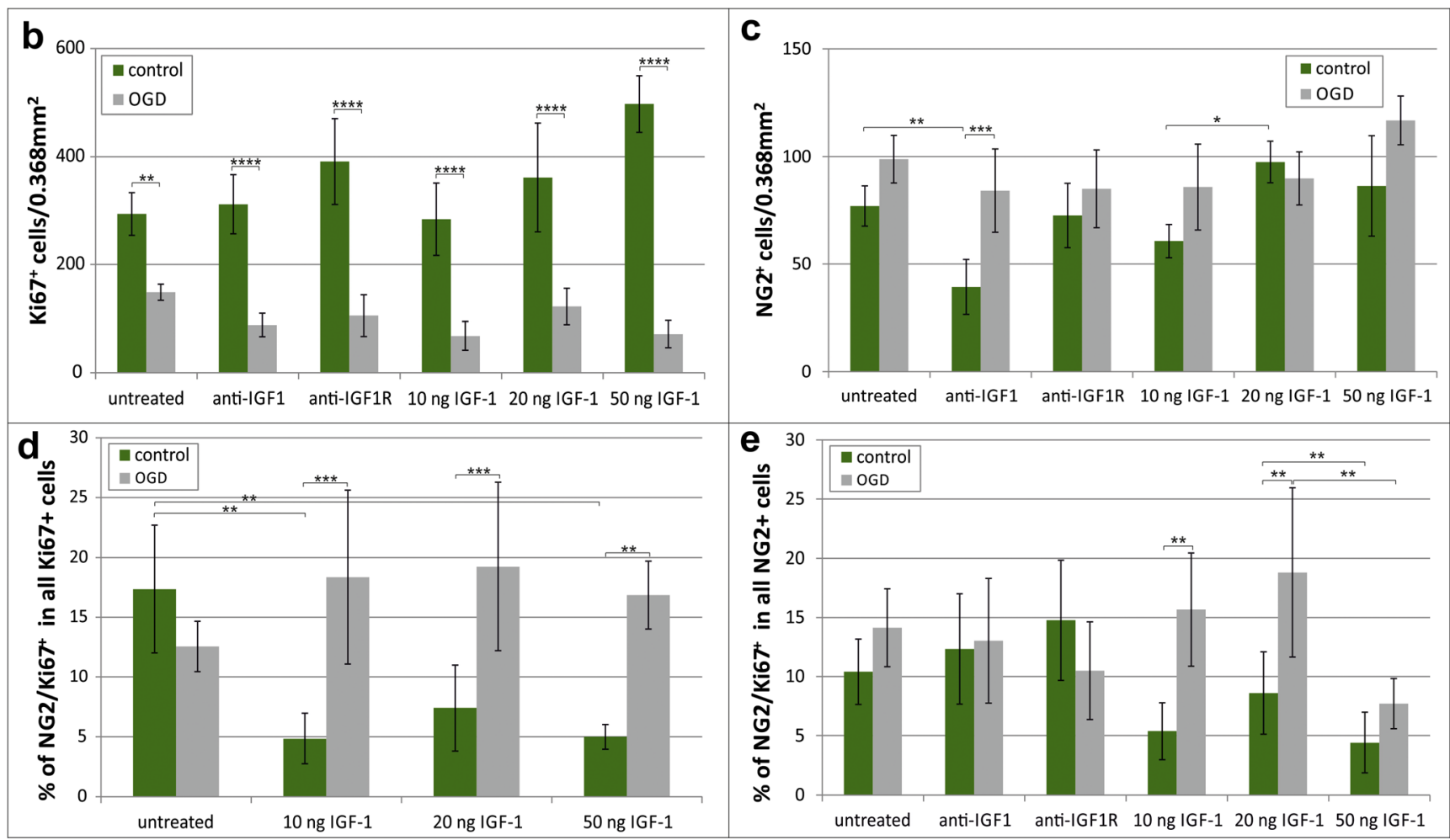

Fig. 4 (continued)

were treated with $50 \mathrm{ng}$ IGF-1 after OGD $(p<0.05)$. As shown, neither neutralizing IGF-1 nor blocking its receptor had an impact on the number of Olig2-expressing cells in the hippocampal slices (Fig. 5b). This observation suggests
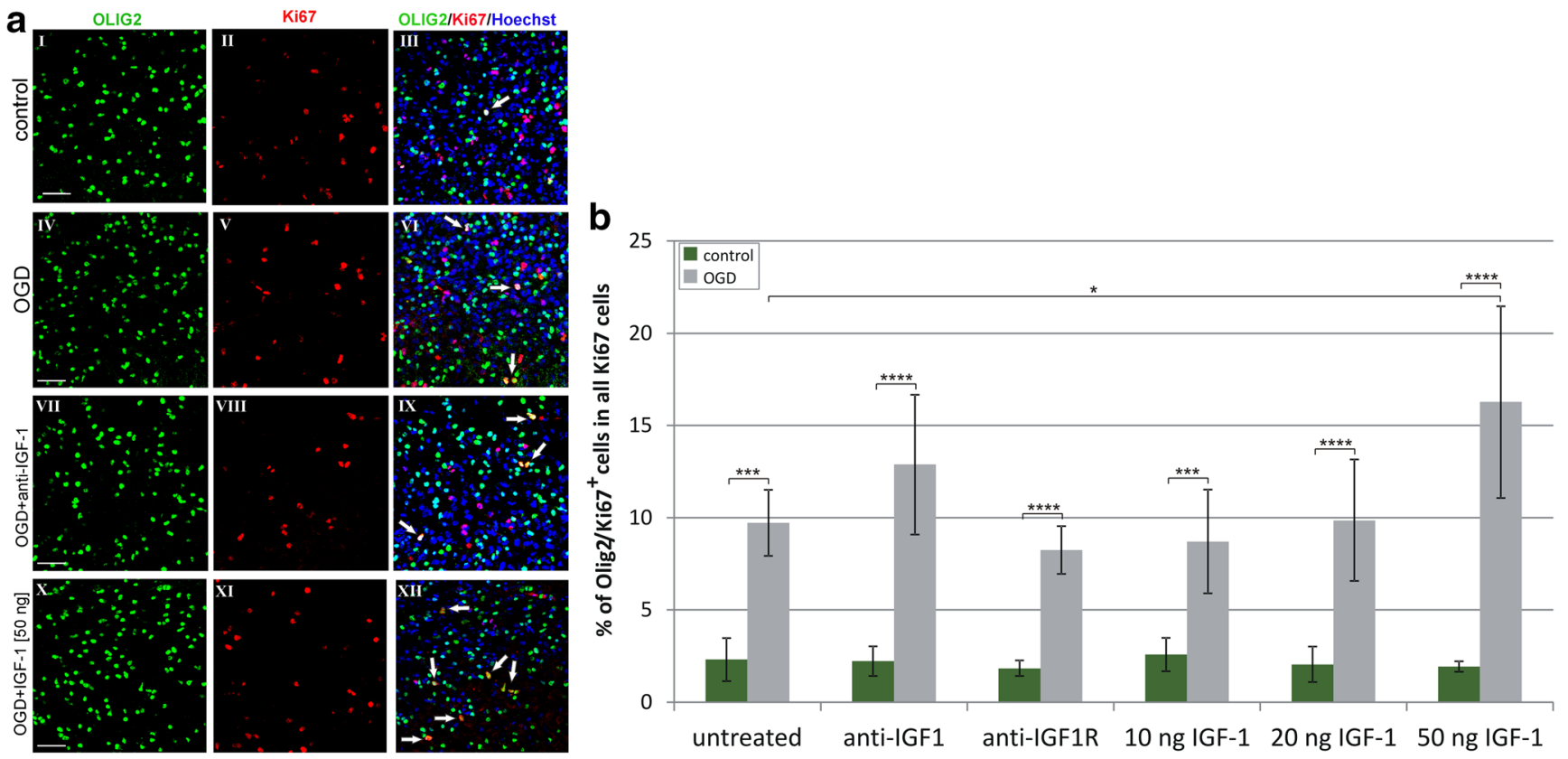

Fig. 5 Impact of oxygen and glucose deprivation followed by various treatments on proliferation of oligodendroglial cells (labeled with the lineage-specific marker Olig2) in the organotypic hippocampal slices, determined 5 days after the insult. a Immunolabeled oligodendrocytes $\left(\mathrm{Olig} 2^{+}\right.$, green) and proliferating cells visualized by anti-Ki67 antibody (red). Cell nuclei are stained with Hoechst 33342 (blue). White arrows indicate dividing cell nuclei in oligodendrocytes $\left(\mathrm{Olig} 2^{+} / \mathrm{Ki} 67^{+}\right)$.
Microphotographs show hippocampal slices cultured in control conditions (I-III), affected by OGD (IV-VI) and after different treatments of OGD-injured cultures (VII-XII). Scale bar is equivalent of $50 \mu \mathrm{m}$. b Calculation of the dividing oligodendroglial fraction in the entire pool of cycling cells. The values are mean \pm standard deviation; the statistical differences were considered as significant if: $* p<0.05, * * * p<0.001$, $* * * * p<0.0001$ 
Fig. 6 Morphometric analysis of the branched, NG2-positive oligodendrocytes in the organotypic hippocampal slices. The graphical masks of an individual cell were drawn by application of NeuronJ software (a) and then subjected to Sholl analysis (b). Number of intersections of cell branches with consecutive concentric circles around cell body were recorded (c), and a number of quantitative descriptors was calculated (d) The differences were recognized as significant if $* p<0.05$

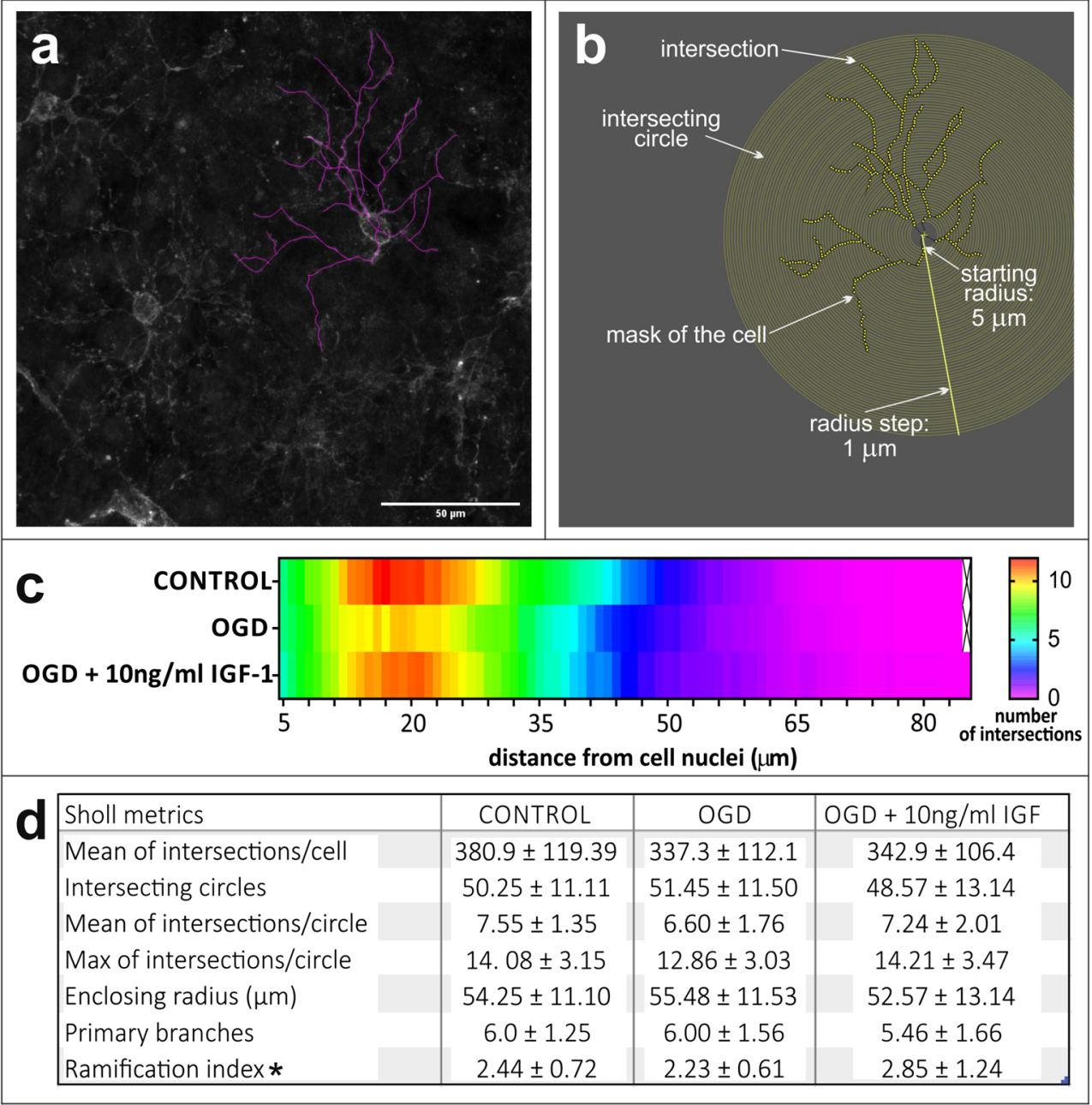

that in the selected concentrations, IGF-1 might be effective in promoting oligodendroglial proliferation, which is not limited however to the progenitor stage only.

\section{Supplementation of IGF-1 Stimulates Ramification of Oligodendroglial Processes in Hippocampal Slices}

With regard to the fact that one of the descriptors of oligodendrocyte differentiation is the complexity of the elaborated cell processes, a morphometric examination of the multibranched NG2-positive immature oligodendrocytes was performed. Accordingly, the labeled cells grown in the lowest, $10 \mathrm{ng} /$ mg IGF-1 concentrations, were subjected to the Sholl analysis (Fig. 6a, b).

As shown by the linear plot (Fig. 6c), the control cells were the most branched, in spite that the number of primary branches and enclosing radius (indicating the size of the cell) were similar to the parameters recorded for the cells injured by the OGD procedure. Additionally, among numerous descriptors calculated for the relevant images (Fig. 6d), the ramification index (corresponding to the ratio of the maximum number of intersections to the number of primary branches) pointed to the most interesting differences between the examined variants of experimental work. Namely, statistically significant differences $(p<0.05)$ were observed when the hippocampal slices subjected to the OGD procedure were compared with those treated with $10 \mathrm{ng} / \mathrm{ml} \mathrm{IGF-1} \mathrm{after} \mathrm{the} \mathrm{insult.} \mathrm{This} \mathrm{indi-}$ cated that supplementing the culture media after OGD with IGF-1 in as low concentrations as $10 \mathrm{ng} / \mathrm{ml}$ led increasing the number of intersections in the cell processes, thus promoting their ramification and indicating the role of this growth factor in oligodendrocyte differentiation.

\section{IGF-1 Secretion by Neonatal Glial Cells Is Differently Affected by Hypoxic-Ischemic Condition In Vitro}

To address the question if any type of glia may be responsible for the observed changes in the endogenous IGF-1 content at $24 \mathrm{~h}$ after the applied insult, the secretion of this factor was evaluated in the obtained glial monocultures. As revealed by the quantitative biochemical studies, an autocrine expression of IGF-1 strictly depended on the type of glial cell. Accordingly, the level of IGF-1 measured in culture media conditioned by astrocytes was a whole order of magnitude 

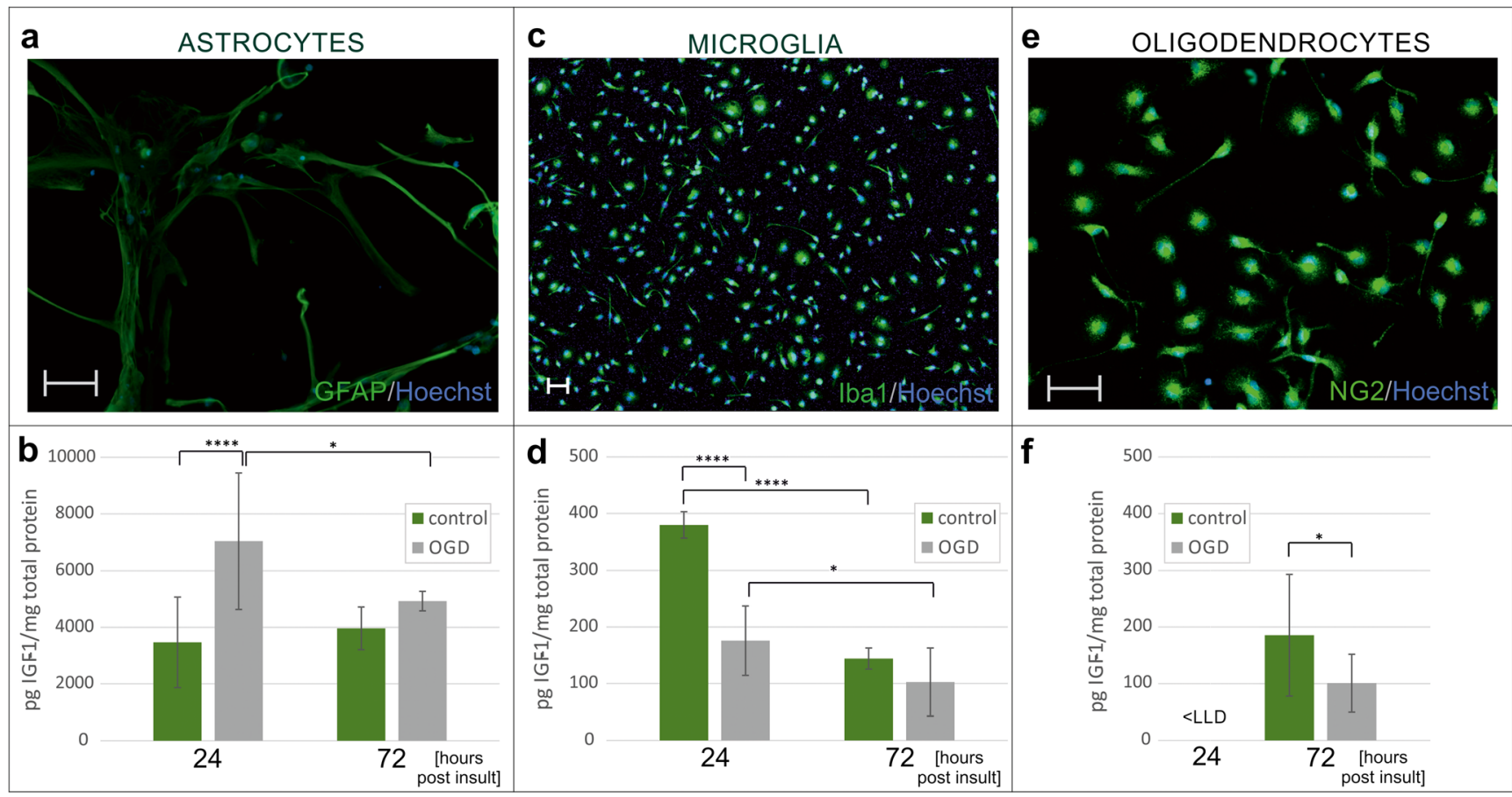

Fig.7 Quantification of IGF-1 in the culture supernatants of astrocytes (a, b), microglia (c, d) and oligodendrocytes (e, f) 24 and $72 \mathrm{~h}$ after oxygenglucose deprivation, respectively. Monocultures are stained with the

lineage-specific markers (green), while cell nuclei are visualized with Hoechst 33342 (blue). Scale bars corresponds to $50 \mu \mathrm{m}$. Presented values are mean \pm standard deviation $* p<0.05, * * * * p<0.0001$

higher than those enriched by IGF-1 released by either microglia or differentiating oligodendrocytes.

While IGF-1 secretion by astrocytes was 1.5 -fold increased during the first day after OGD when compared with control values $(p<0.0001$; Fig. $7 \mathrm{a}, \mathrm{b})$, the amounts of this growth factor released by microglia is 2 times lower than in control culture ( 1 day after OGD; $p<0.0001$; Fig. $7 \mathrm{c}, \mathrm{d}$ ). Similar effect was observed during examination of oligodendrocyte cultures (3 days after OGD; $p<0.05$; Fig. 7e, f). Concentration of IGF-1 in media collected from oligodendrocyte culture at $24 \mathrm{~h}$ after OGD was below the lower limit of detection; therefore, the additional measurements were performed in cell lysates. The mean amount of the intracellular IGF-1 in controls was estimated at $859.03 \pm 206.47 \mathrm{pg} / \mathrm{mg}$ total protein content), while after $1 \mathrm{~h}$ after OGD, it was reduced to $765.81 \pm 192.45 \mathrm{pg} / \mathrm{mg}$ total protein $(p=0.4)$.

\section{Supplementing Oligodendroglial Cultures with Exogenous IGF-1 Does Not Affect Cell Proliferation but Promotes Their Differentiation}

Results obtained during studies on hippocampal slices were verified by establishing primary cultures of rat oligodendrocyte progenitors, performing OGD procedure to evoke HI stress and applying the same treatments as for the cultured hippocampal slices. Likewise, the opposite experimental approaches were used. The first one was based on eliminating the IGF-1 influence by either neutralizing this factor or blocking its receptor with specific antibodies. The second approach involved supplementing culture media immediately after the injury with rat recombinant IGF-1 at concentrations $10 \mathrm{ng} / \mathrm{ml}$ and $50 \mathrm{ng} / \mathrm{ml}$. To evaluate the results of the applied treatments on proliferation and differentiation of cultured oligodendrocytes, the expression of the selected lineage specific markers was examined by means of immunocytochemistry 5 days after OGD injury. Accordingly, as deduced from calculation of the immunolabeled Ki67-positive cells, addition of IGF-1 immediately after OGD did not stimulated oligodendrocyte proliferation (Fig. 8a, b). However, neutralization of oligodendrocyte-derived IGF-1 resulted in a significant ( $p$ $<0.01$ ) decrease of the number of dividing cells (Fig. 8b), suggesting an autocrine effect on the cell proliferation.

The obtained results also showed that applying any type of the designed treatments after OGD resulted in a significant decrease in fraction of Olig2 ${ }^{+}$positive cells, as deduced from estimating number of cells in which this transcription factor was localized in the cell nuclei (Fig. 8c, d). Subsequent analysis of differentiating, CNP-positive oligodendrocytes, characterized by more complex morphology revealed that IGF-1 concentration of $50 \mathrm{ng} / \mathrm{mlin}$ culture media after OGD reduced the number of maturing cells (to $89.9 \% \pm 5.9 \%$ of $\mathrm{CNPase}^{+}$ cells), when compared with either OGD-subjected and untreated cell cultures $\left(96.6 \% \pm 1.9 \%\right.$ of $\mathrm{CNPase}^{+}$cells; $p<0.05$ ) or to the OGD-subjected cultures supplemented with IGF-1 at concentration of $10 \mathrm{ng} / \mathrm{ml}\left(96.3 \% \pm 2.7 \%\right.$ CNPase $^{+}$ cells; $p<0.05$; Fig. $8 \mathrm{e}$, f). Those results point to the important 


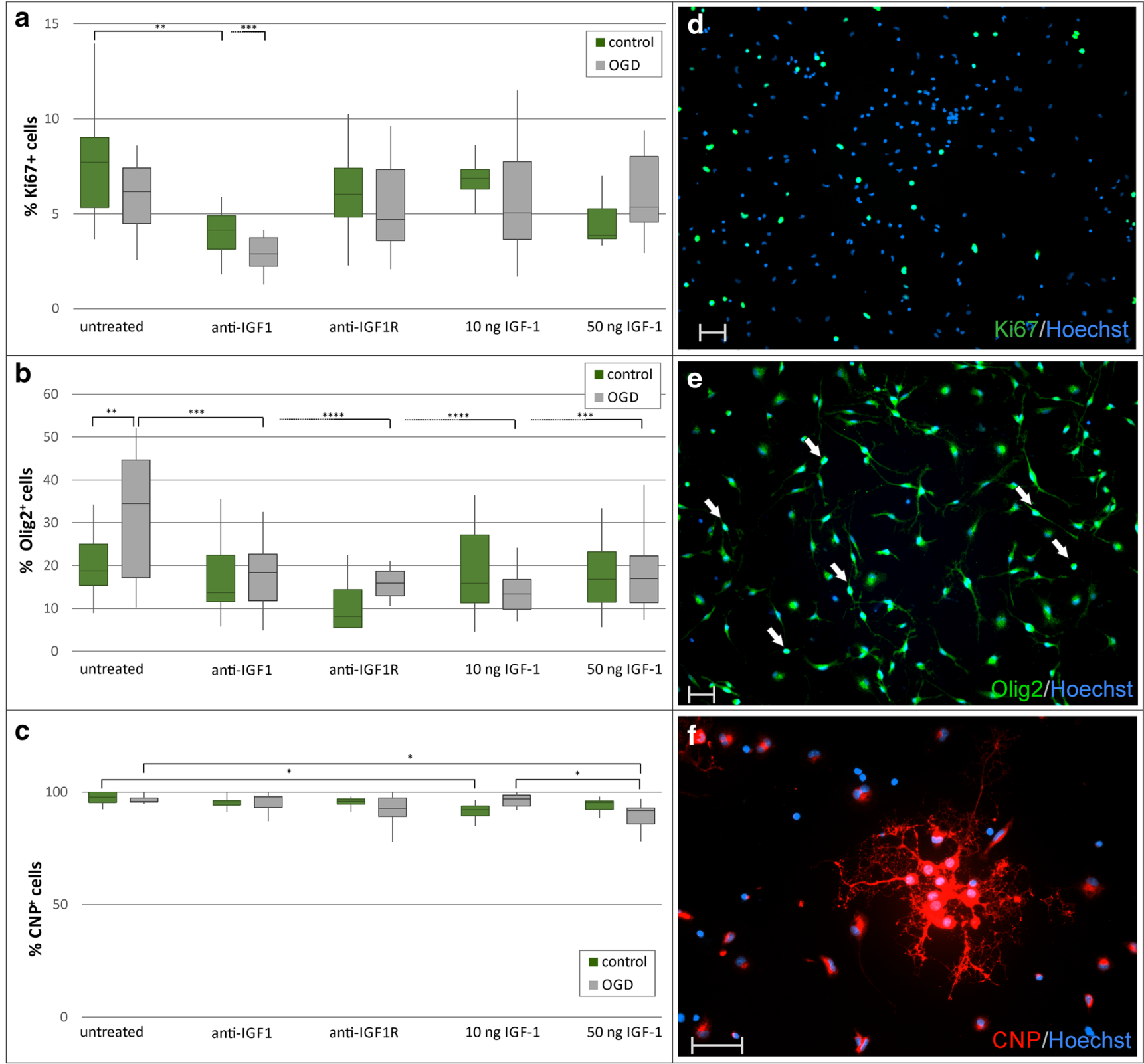

Fig.8 Immunocytochemical analysis of oligodendrocyte cultures fixed 5 days after OGD followed by testing various experimental treatments. The applied antibodies included anti-Ki67 to label proliferating cells (a, b), as well as anti-Olig2 to stain transcription factor localized in the cell nuclei $(\mathbf{c}, \mathbf{d})$ and antiCNPase $(\mathbf{e}, \mathbf{f})$ to visualize differentiating

role of the local IGF-1 concentration in regulation of oligodendrocyte maturation.

\section{Discussion}

The cells forming the nervous tissue are functionally interdependent and interplay by both responding to and releasing numerous factors, which altogether create the local tissue microenvironment. This is especially pronounced in the case of oligodendrocytes. Results are showed as box and whisker graphs. A vertical line in box represents a median of the obtained values. Bottom and upper edges of the box represent the first and third quartile, respectively. Whiskers indicate the minimum and the maximum value of the results. Scale bar equals $50 \mu \mathrm{m}$

gliogenesis process and oligodendrocyte differentiation, in which the subsequent developmental stages are strictly regulated by the in situ concentration of instructive signals [4, 52-55]. Among them, the IGF-1 is thought to be one of the most important factors engaged in regulation of the majority of processes associated with oligodendrocyte functioning.

The growing list of evidence points to the altered availability of IGF-1 in a wide spectrum of neurodegenerative disorders. While after traumatic brain injury (TBI) the endogenous IGF-1 level has been shown to increase, in multiple sclerosis 


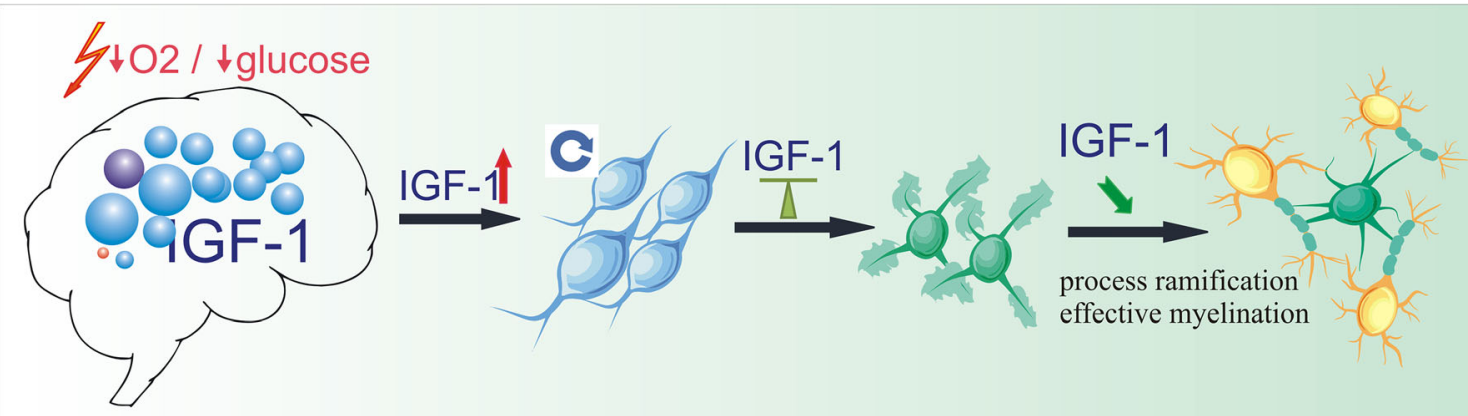

Fig. 9 Potential therapeutic strategy aiming at promotion of oligodendrocyte maturation. Perinatal asphyxia leads to a transient increase of IGF-1 level in neonatal brain, inhibiting cell proliferation in developing brain. In the later period, IGF-1 stabilizes on the physiological level. OPCs deficiency triggered by perinatal asphyxia is compensated by

(MS), which is one of the most deeply studied demyelinating diseases, a local deficiency of this growth factor has been observed, often within the areas of demyelination. Alteration of IGF-1 level is thought to be also one of the features of the white matter disorders developing in a result of the experienced perinatal asphyxia. Since the neonatal period coincidences with the most active processes of gliogenesis, oligodendrocyte survival and differentiation, as well as myelination of the newly derived neurons, the insufficient amounts of endogenous trophic factors, including IGF-1, might unfortunately efficiently contribute to the resulting myelin deficiency, or/ and malformation of the white matter tracts [56-59]. The recent clinical studies confirmed that the IGF-1 level in serum is significantly decreased in newborns with hypoxic-ischemic encephalopathy [60]. A number of preclinical studies have been performed based on IGF-1 systemic administration in order to at least partially alleviate deleterious effects of the experienced birth asphyxia. Depending on the way and mode of the IGF-1 administration (for instance intraventricular versus intranasal or subcutaneous, in one or several repeated doses, within narrow therapeutic window or after the onset of first neurological symptoms, alone, or combined with other therapy etc.), different beneficial effects have been reported in animal models of birth asphyxia. Among others, increased cell proliferation, rescued loss of Olig2-positive cells in the white matter and reduced lesion volume were observed [61-64]. To date however, the moderate therapeutic hypothermia is the sole clinical intervention after perinatal asphyxia. Moreover, even if applied within the narrow therapeutic window and for a prolonged time, hypothermia does not always confer neuroprotection and has been shown to be unsuccessful in more severe cases of asphyxic episodes. Actually, it seems that hypothermia neither provides complete brain protection nor stimulates the repair necessary for improving the neurodevelopmental outcome. New treatment options are therefore urgently needed to protect fragile developing brains from the fatal consequences of hypoxic-ischemic damage and to restore their proper physiological functioning [65-67]. cycling and differentiating oligodendrocytes. IGF-1 administration (or enhancement of IGF-1 expression by cells within the nervous tissue) would promote branching of cell processes, improving efficiency of myelination process

Recently, there is an ever growing recognition concerning the role of autocrine/paracrine IGF-1 signaling in brain development and metabolism $[68,69]$. This factor is known to be distributed by the circulating blood system due to endocrine production under control of growth hormone (GF) and actively transported to the CNS through the choroid plexus by transcytosis; however, it is also secreted in situ by various cell types [70, 71]. Recent findings highlight the role of cells inhabiting the nervous tissue as a source of locally available IGF-1 in tissue microenvironment. It is hypothesized the endogenous IGF-1 released in situ by neural cells exerts the main pleiotropic effects on the neighboring cell functions.

To address the issue about the role of central versus paracrine IGF-1 secretion in oligogliogenesis, a study based on a step-wise approach was performed. First of all, the endogenous quantities of IGF-1 were determined in the rat brains after the insult triggered by the transient hypoxic-ischemic conditions. After considering the timeline of neonatal brain development, especially in the context of progress in myelination of various brain regions in humans versus rodents, P7 rats, which correspond to 30th postconceptional day (PC), were selected for performing the animal model of perinatal asphyxia [72-74]. Accordingly, 7th postnatal day in rats is still within the peak on oligogliogenesis and just prior to the onset of myelination in the hippocampus (33 PC), striatum (34 PC), and corpus callosum (35 PC). These facts seemed to be of vital importance in the context of our previous findings which showed that myelination in the indicated brain regions 10 weeks after the HI was significantly deficient or aberrant [75]. Apart from the existence of the malformed myelin sheaths in the hippocampus, the data obtained in another study showed the impaired processes of neurogenesis and gliogenesis in the rat hippocampus in the in vivo model of perinatal asphyxia [76]. Taking into consideration the above mentioned observations, together with the proven cognitive and intellectual dysfunctions being the main and commonest consequences of the experienced perinatal asphyxia [69, 
77-81], the hippocampal region was subjected to close (i.e., in vivo and ex vivo) scrutiny.

The applied approach led to interesting observations about the significant, transient increase of the IGF-1 amounts in neonatal brains $24 \mathrm{~h}$ after the insult. However, the similar effect was absent in the examined hippocampi. To further evaluate, whether the increased IGF-1 quantities are derived from the central sources and are due to the intensified penetration of this factor via neonatal BBB, the subsequent indepth studies were based on series of ex vivo experiments, which allowed eliminating the influence of the peripheral IGF-1, distributed by the circulatory system. This approach confirmed the previous in vivo observations concerning the unaltered IGF-1 level in the nervous tissue localized within the hippocampal regions. However, in spite of the lack of alterations in the IGF-1 amounts, a decreased rate of cell proliferation was observed within the ex vivo examined hippocampal area. Interestingly, the proportion of the dividing OPCs to the rest of the cycling neural cells remained unchanged which was due to the observed accelerated proliferation of oligodendroglial progenitors.

This new observation could be contributed to the application of physiologically relevant normoxic conditions for the entire performed study. As revealed by the data obtained from one of our recent studies [51], oxygen level is one of the major factors affecting proliferation and differentiation of oligodendrocytes. To date, the majority of the published studies on glial cells were conducted in standard laboratory conditions, i.e., the cells were cultured in ambient (corresponding to 16$21 \%$ ) oxygen concentration, which however was shown to accelerate cell maturation. In the present study, the organotypic slices were cultured after OGD in conditions corresponding to physiological normoxia, i.e., in $5 \% \mathrm{O}_{2}$, relevant to physiological conditions found in the nervous tissue [82-84]. The period of cell proliferation was therefore extended, and the deficiency of oligodendrocyte progenitors was supposedly compensated for in response to the insult. Additionally, due to testing various doses of IGF-1, the composition of the culture medium was seriously restricted. Namely, ITS supplement, which is routinely added to cell and slice cultures, was not used during the present study, due to its containing insulin, transferrin, and selenium. Adding transferrin is also supposed to accelerate oligodendroglial differentiation [85]. Transferrin might also induce cell death by ferroptosis [86]. Taken together, the process of oligodendroglial maturation in the presently created conditions seems to have slowed-down in comparison with the previous observations and thus more resembling physiological proceeding of the examined process. Accordingly, as shown by the present study, although IGF-1 levels at macroscopic examinations seemed to be unaltered, the local IGF-1 concentrations, and its bioavailability due to in situ secretion by glial cells could modulate oligodendroglial functioning. Taking into consideration the IGF-1 half-life (counting for few-minutes), the local paracrine effect might be critical for normal oligodendroglial development.

Likewise, with the aim of precisely evaluating the IGF-1 impact on oligodendroglial differentiation in the nervous tissue microenvironment, a morphometric analysis of the differentiating cell morphology by means of the Sholl software was applied. This allowed us to assess the degree of ramification of the cell processes, elaborated during the differentiation process to enwrap around axons and to form a myelin segment. Oligodendrocytes are known to be able to myelinate several neighboring axons; thus, subsequent myelin segments are made up by different oligodendroglial cells. From this point of view, there is no need for cells to elongate their processes in search of axons to be myelinated. Oligodendroglial response to local instructive signals, derived from neurons and triggering myelinogenesis [87-89], seems to be assured rather by high complexity of process branching. Numerous cell extensions allow sensing in situ the paracrine signals, as well as those provided by direct cellular interactions (cell-to-cell contacts). As alluded to above, the examination of several morphometric descriptors of oligodendroglial cells differentiating in the microenvironment of the nervous tissue of the hippocampal region revealed that the IGF-1 impacted significantly on the ramification of cell processes, even in the lowest of the tested IGF-1 concentrations. As therefore could be deduced from the presented ex vivo study, treatment with the tested growth factor is effective in stimulating OPC proliferation, and it might efficiently improve cell maturation. This finding is important in the context of the previously reported observations of retarded oligodendrocyte differentiation and aberrant myelinogenesis after the neonatal hypoxic-ischemic episode $[75,90]$. It could also be correlated with clinical observations of the white matter disturbances in the brains of babies who survived perinatal asphyxia and associated with the following underdevelopment of enfant cognitive processes [91-94]. As therefore could be deduced from the presented studies, a transient increase in the IGF-1 level in neonatal brains during the first $24 \mathrm{~h}$ after hypoxic-ischemic insult leads to an inhibition of oligodendroglial proliferation, which is afterwards compensated for by the increased number of dividing cells in the later period after perinatal asphyxia, when IGF-1 stabilizes at the physiological level. It seemed to be reasonable to administrate the IGF-1 in that period as a pharmacological treatment to promote oligodendrocyte maturation and to prevent the development of white matter disorders (Fig. 9).

Those conclusions were further supported by the data obtained from the subsequent studies aimed at testing the influence of various IGF-1 doses on oligodendrocytes in vitro conditions mimicking physiological normoxia. Accordingly, an analysis carried out on CNP-ase ${ }^{+}$oligodendrocytes characterized by complex morphology typical of the advanced stage of the maturation process, confirmed that IGF-1 was highly 
efficient in preventing the arrestment of oligodendrocyte differentiation after the hypoxic-ischemic insult. Moreover, our results indicate that neonatal oligodendrocytes are themselves a source of this factor. Contrary to astrocytes, however, hypoxic-ischemic injury negatively influences IGF-1 release by oligodendrocytes.

Among the investigated types of glial cells in the context of IGF-1 secretion, astrocytes attract a special attention. They were shown to express both IGF-1 and its receptors, which play a crucial role in regulating glucose uptake by these cells and thus providing neurons with metabolic substrates on demand [95-99]. The increased secretion of this growth factor by astrocytes exerted neuroprotective effect on hippocampal neurons after traumatic brain injury [100]. The impact of IGF1 on the increase in number of astrocytes, as well as elevated amount of connexins and gap junctions was reported [101]. Additionally, insulin-like growth factor 1 gene therapy was shown to promote astrocyte branching [102]. Interestingly, as shown in the present study, astrocytes actively respond to temporal hypoxic-ischemic condition by significantly upregulating secretion of IGF-1 protein during first $24 \mathrm{~h}$ after the insult.

There is also the growing recognition of the role the microglial cells play in neonatal neurodevelopment. Namely, this cell population $\left(\mathrm{CD} 11 \mathrm{c}^{+}\right)$exhibits unique properties during the early postnatal period, providing neurosupportive and myelinogenic signals [103, 104]. Oligodendrocyte-microglia cross-talk has been shown to play an important role both under physiological conditions (during neurodevelopment and aging) and in different pathological disorders [105-108]. Moreover, there is a growing list of evidence that IGF-1 is involved in modulation of neuroimmunological processes [109-112]. Since neuroinflammation is associated with the majority of diseases distinguished as white matter disorders and associated with hypo- or demyelination of the nervous system $[113,114]$, this growth factor is considered to be one of the main tools in combating the mentioned neurodegenerative disorders. Postulated involvement of IGF-1 in promoting angiogenesis [115] and in this way helping to overcome oxygen and metabolic crisis within the tissue affected by transient hypoxia-ischemia, might additionally contribute to initiation of neuroregenerative processes. In this context, the downregulation of IGF-1 expression by microglial cells, shown in the present study, may contribute not only to oligodendrocyte malfunctioning but also to in situ modulation of neuroinflammation.

Taken together, the accumulating evidences of the important influence of IGF-1 in the early development of the nervous system indicate the major role of autocrine source of this compound, essential for proliferation and maturation of neural cells and establishing cellular interactions. In our previous neurodevelopmental studies, we have shown that even subtle, physiological changes in composition of local tissue microenvironment (specific for a given brain region) are potent to drive commitment and differentiation of neonatal oligodendrocyte progenitors [54]. Local concentration of IGF-1, resulting among others from autocrine activity of macro- and microglial cell, de facto modulates in situ cell functioning. It seems to be especially important for oligodendrocytes and their progenitors, which are known to be vulnerable to different types of insults (including hypoxic-ischemic injury) and extremely sensitive to external stimuli, present either in normal or pathophysiological microenvironment. Thus fine tuning of IGF-1 availability in extracellular compartments could turn out to be crucial for completing a multistep process of oligodendrocyte differentiation, which manifests itself by acquiring ability for myelinogenesis.

Keeping in mind diversified secretory response of glial cells to hypoxia-ischemia, leading to a changed tissue homeostasis and limited effectiveness of strategies based on IGF-1 administration, potential alternative strategies to promote neuroreparative processes could be considered [116, 117]. It seems reasonable to indicate the cells forming neural tissue as a target of pharmacological interventions in pathological conditions affecting CNS. Instead of-or in addition to- supplying exogenously IGF-1, which has to cross the BBB to exert its pleiotropic effects, the medicaments (like for instance small molecules, cAMP), might be preclinically tested and used in modulating microglia response to insult (e.g., promoting polarization between M1 proinflammatory and M2 antiinflammatory phenotypes) and in this way enhance endogenous in situ IGF-1 release to the local tissue microenvironment. Such an indirect strategy, based on targeting other types of neural cells, might be beneficial for stabilizing tissue homeostasis thus improving oligodendrocyte functioning in pathophysiological conditions and contributing to restorative processes.

Authors' Contributions Justyna Janowska established the primary cultures of rat oligodendrocytes and the cultures of organotypic hippocampal slices, as well as performed all the biochemical studies and Sholl analysis. Justyna Gargas was an expert in culturing primary astrocytes and microglia, as well as in immunocytochemistry. Malgorzata Ziemka-Nalecz performed all in vivo experiments, including rat model of perinatal asphyxia. Teresa Zalewska consulted the entire research project. Joanna Sypecka designed the project, coordinated the research, performed the statistical analysis of the data, and wrote the manuscript. All authors reviewed the manuscript.

Funding Information This study was financially supported by NCN (National Science Centre, Poland) grant no.2014/15/B/NZ4/01875.

\section{Compliance with Ethical Standards}

Conflict of Interest The authors declare that they have no conflict of interest.

Ethics Approval and Consent to Participate The international and national principles of good practice for the care and use of animals were 
strictly followed. All the procedures carried on the animals were approved by the Ethics Committee on Animal Care and Use (indicated by Ministry of Science and Higher Education, Poland).

Open Access This article is licensed under a Creative Commons Attribution 4.0 International License, which permits use, sharing, adaptation, distribution and reproduction in any medium or format, as long as you give appropriate credit to the original author(s) and the source, provide a link to the Creative Commons licence, and indicate if changes were made. The images or other third party material in this article are included in the article's Creative Commons licence, unless indicated otherwise in a credit line to the material. If material is not included in the article's Creative Commons licence and your intended use is not permitted by statutory regulation or exceeds the permitted use, you will need to obtain permission directly from the copyright holder. To view a copy of this licence, visit http://creativecommons.org/licenses/by/4.0/.

\section{References}

1. Boulanger JJ, Messier C (2014) From precursors to myelinating oligodendrocytes: contribution of intrinsic and extrinsic factors to white matter plasticity in the adult brain. Neuroscience 269:343366. https://doi.org/10.1016/j.neuroscience.2014.03.063

2. Ozgen H, Baron W, Hoekstra D, Kahya N (2016) Oligodendroglial membrane dynamics in relation to myelin biogenesis. Cell Mol Life Sci 73:3291-3310. https://doi.org/10. 1007/s00018-016-2228-8

3. Philips T, Rothstein JD (2017) Oligodendroglia: metabolic supporters of neurons. J Clin Invest 127:3271-3280. https://doi.org/ 10.1172/JCI90610

4. Forbes TA, Gallo V (2017) All wrapped up: environmental effects on myelination. Trends Neurosci 40:572-587. https://doi.org/10. 1016/j.tins.2017.06.009

5. Werner H, LeRoith D (2014) Insulin and insulin-like growth factor receptors in the brain: physiological and pathological aspects. Eur Neuropsychopharmacol 24:1947-1953. https://doi.org/10. 1016/j.euroneuro.2014.01.020

6. Subramaniam S, Shahani N, Strelau J, Laliberté C, Brandt R, Kaplan D, Unsicker K (2005) Insulin-like growth factor 1 inhibits extracellular signal-regulated kinase to promote neuronal survival via the phosphatidylinositol 3-kinase/protein kinase A/c-Raf pathway. J Neurosci 25:2838-2852. https://doi.org/10.1523/ JNEUROSCI.5060-04.2005

7. Himpe E, Kooijman R (2009) Insulin-like growth factor-I receptor signal transduction and the Janus kinase/signal transducer and activator of transcription (JAK-STAT) pathway. Biofactors 35: 76-81. https://doi.org/10.1002/biof.20

8. Siddle K (2011) Signalling by insulin and IGF receptors: supporting acts and new players. J Mol Endocrinol 47:R1-R10. https://doi.org/10.1530/JME-11-0022

9. Kleinridders A (2016) Deciphering brain insulin receptor and insulin-like growth factor 1 receptor Signalling. J Neuroendocrinol 28. https://doi.org/10.1111/jne.12433

10. Zheng W, Meng Q, Wang H, Yan F, Little PJ, Deng X, Lin S (2018) IGF-1-mediated survival from induced death of human primary cultured retinal pigment epithelial cells is mediated by an Akt-dependent signaling pathway. Mol Neurobiol 55:19151927. https://doi.org/10.1007/s12035-017-0447-0

11. Ye P, D'Ercole AJ (2006) Insulin-like growth factor actions during development of neural stem cells and progenitors in the central nervous system. J Neurosci Res 83:1-6. https://doi.org/10.1002/ jnr.20688
12. Bondy CA, Cheng CM (2004) Signaling by insulin-like growth factor 1 in brain. Eur J Pharmacol 490:25-31. https://doi.org/10. 1016/j.ejphar.2004.02.042

13. Hurtado-Chong A, Yusta-Boyo MJ, Vergaño-Vera E, Bulfone A, de Pablo F, Vicario-Abejón C (2009) IGF-I promotes neuronal migration and positioning in the olfactory bulb and the exit of neuroblasts from the subventricular zone. Eur J Neurosci 30: 742-755. https://doi.org/10.1111/j.1460-9568.2009.06870.x

14. Yuan H, Chen R, Wu L, Chen Q, Hu A, Zhang T, Wang Z, Zhu X (2015) The regulatory mechanism of neurogenesis by IGF-1 in adult mice. Mol Neurobiol 51:512-522. https://doi.org/10.1007/ s12035-014-8717-6

15. Nieto-Estévez V, Defterali Ç, Vicario-Abejón C (2016) IGF-I: a key growth factor that regulates neurogenesis and synaptogenesis from embryonic to adult stages of the brain. Front Neurosci 10:52. https://doi.org/10.3389/fnins.2016.00052

16. Huang B, Ning S, Zhang Q, Chen A, Jiang C, Cui Y, Hu J, Li H et al (2017) Bisphenol a represses dopaminergic neuron differentiation from human embryonic stem cells through downregulating the expression of insulin-like growth factor 1. Mol Neurobiol 54: 3798-3812. https://doi.org/10.1007/s12035-016-9898-y

17. Kooijman R, Sarre S, Michotte Y, De Keyser J (2009) Insulin-like growth factor I: a potential neuroprotective compound for the treatment of acute ischemic stroke? Stroke 40:e83-e88. https:// doi.org/10.1161/STROKEAHA.108.528356

18. Carlson SW, Madathil SK, Sama DM, Gao X, Chen J, Saatman KE (2014) Conditional overexpression of insulin-like growth factor-1 enhances hippocampal neurogenesis and restores immature neuron dendritic processes after traumatic brain injury. $\mathrm{J}$ Neuropathol Exp Neurol 73:734-746. https://doi.org/10.1097/ NEN.0000000000000092

19. Tien L-T, Lee Y-J, Pang Y, Lu S, Lee JW, Tseng CH, Bhatt AJ, Savich RD et al (2017) Neuroprotective effects of intranasal IGF-1 against neonatal lipopolysaccharide-induced neurobehavioral deficits and neuronal inflammation in the substantia nigra and locus coeruleus of juvenile rats. Dev Neurosci 39:443-459. https://doi. org/10.1159/000477898

20. Bianchi VE, Locatelli V, Rizzi L (2017) Neurotrophic and neuroregenerative effects of GH/IGF1. Int J Mol Sci 18. https:// doi.org/10.3390/ijms18112441

21. Durán-Carabali LE, Arcego DM, Odorcyk FK, Reichert L, Cordeiro JL, Sanches EF, Freitas LD, Dalmaz C et al (2018) Prenatal and early postnatal environmental enrichment reduce acute cell death and prevent neurodevelopment and memory impairments in rats submitted to neonatal hypoxia ischemia. Mol Neurobiol 55:3627-3641. https://doi.org/10.1007/s12035-0170604-5

22. Denti L, Annoni V, Cattadori E, Angela Salvagnini M, Visioli S, Francesca Merli M, Corradi F, Ceresini G et al (2004) Insulin-like growth factor 1 as a predictor of ischemic stroke outcome in the elderly. Am J Med 117:312-317. https://doi.org/10.1016/j. amjmed.2004.02.049

23. Ashpole NM, Sanders JE, Hodges EL, Yan H, Sonntag WE (2015) Growth hormone, insulin-like growth factor-1 and the aging brain. Exp Gerontol 68:76-81. https://doi.org/10.1016/j.exger. 2014.10.002

24. Mangiola A, Vigo V, Anile C, de Bonis P, Marziali G, Lofrese G (2015) Role and importance of IGF-1 in traumatic brain injuries. Biomed Res Int 2015:736104-736112. https://doi.org/10.1155/ 2015/736104

25. Gray SM, Thorner MO (2017) Spatiotemporal regulation of insulin-like growth factor-1 and its receptor in the brain: Is there a role for growth hormone? Endocrinology 158:229-232. https:// doi.org/10.1210/en.2016-1884

26. Baud O, Berkane N (2019) Hormonal changes associated with intra-uterine growth restriction: impact on the developing brain 
and future neurodevelopment. Front Endocrinol (Lausanne) 10: 179. https://doi.org/10.3389/fendo.2019.00179

27. Freude S, Leeser U, Müller M, Hettich MM, Udelhoven M, Schilbach K, Tobe K, Kadowaki T et al (2008) IRS-2 branch of IGF-1 receptor signaling is essential for appropriate timing of myelination. J Neurochem 107:907-917. https://doi.org/10.1111/ j.1471-4159.2008.05631.x

28. Riikonen R (2017) Insulin-like growth factors in the pathogenesis of neurological diseases in children. Int J Mol Sci 18. https://doi. org/10.3390/ijms18102056

29. Vicario-Abejón C, Yusta-Boyo MJ, Fernández-Moreno C, de Pablo F (2003) Locally born olfactory bulb stem cells proliferate in response to insulin-related factors and require endogenous insulin-like growth factor-I for differentiation into neurons and glia. J Neurosci 23:895-906

30. Hsieh J, Aimone JB, Kaspar BK, Kuwabara T, Nakashima K, Gage FH (2004) IGF-I instructs multipotent adult neural progenitor cells to become oligodendrocytes. J Cell Biol 164:111-122. https://doi.org/10.1083/jcb.200308101

31. Shi B, Ding J, Liu Y, Zhuang X, Zhuang X, Chen X, Fu C (2014) ERK1/2 pathway-mediated differentiation of IGF-1-transfected spinal cord-derived neural stem cells into oligodendrocytes. PLoS One 9:e106038. https://doi.org/10.1371/journal.pone. 0106038

32. Jiang F, Frederick TJ, Wood TL (2001) IGF-I synergizes with FGF-2 to stimulate oligodendrocyte progenitor entry into the cell cycle. Dev Biol 232:414-423. https://doi.org/10.1006/dbio.2001. 0208

33. Frederick TJ, Wood TL (2004) IGF-I and FGF-2 coordinately enhance cyclin D1 and cyclin E-cdk2 association and activity to promote G1 progression in oligodendrocyte progenitor cells. Mol Cell Neurosci 25:480-492. https://doi.org/10.1016/j.mcn.2003. 11.015

34. Lin S, Fan L-W, Pang Y, Rhodes PG, Mitchell HJ, Cai Z (2005) IGF-1 protects oligodendrocyte progenitor cells and improves neurological functions following cerebral hypoxia-ischemia in the neonatal rat. Brain Res 1063:15-26. https://doi.org/10.1016/ j.brainres.2005.09.042

35. Aberg ND, Johansson UE, Aberg MAI et al (2007) Peripheral infusion of insulin-like growth factor-I increases the number of newborn oligodendrocytes in the cerebral cortex of adult hypophysectomized rats. Endocrinology 148:3765-3772. https://doi.org/ 10.1210/en.2006-1556

36. Cui Q-L, Almazan G (2007) IGF-I-induced oligodendrocyte progenitor proliferation requires PI3K/Akt, MEK/ERK, and Src-like tyrosine kinases. J Neurochem 100:1480-1493. https://doi.org/10. 1111/j.1471-4159.2006.04329.x

37. Hua K, Forbes ME, Lichtenwalner RJ, Sonntag WE, Riddle DR (2009) Adult-onset deficiency in growth hormone and insulin-like growth factor-I alters oligodendrocyte turnover in the corpus callosum. Glia 57:1062-1071. https://doi.org/10.1002/glia.20829

38. Romanelli RJ, Mahajan KR, Fulmer CG, Wood TL (2009) Insulin-like growth factor-I-stimulated Akt phosphorylation and oligodendrocyte progenitor cell survival require cholesterolenriched membranes. J Neurosci Res 87:3369-3377. https://doi. org/10.1002/jnr.22099

39. Chesik D, De Keyser J, Bron R, Fuhler GM (2010) Insulin-like growth factor binding protein-1 activates integrin-mediated intracellular signaling and migration in oligodendrocytes. $\mathrm{J}$ Neurochem 113:1319-1330. https://doi.org/10.1111/j.14714159.2010.06703.x

40. Ness JK, Mitchell NE, Wood TL (2002) IGF-I and NT-3 signaling pathways in developing oligodendrocytes: differential regulation and activation of receptors and the downstream effector Akt. Dev Neurosci 24:437-445. https://doi.org/10.1159/000069050
41. Palacios N, Sánchez-Franco F, Fernández M et al (2005) Intracellular events mediating insulin-like growth factor Iinduced oligodendrocyte development: modulation by cyclic AMP. J Neurochem 95:1091-1107. https://doi.org/10.1111/j. 1471-4159.2005.03419.x

42. Bibollet-Bahena O, Almazan G (2009) IGF-1-stimulated protein synthesis in oligodendrocyte progenitors requires $\mathrm{PI} 3 \mathrm{~K} / \mathrm{mTOR} /$ Akt and MEK/ERK pathways. J Neurochem 109:1440-1451. https://doi.org/10.1111/j.1471-4159.2009.06071.x

43. Min J, Singh S, Fitzgerald-Bocarsly P, Wood TL (2012) Insulinlike growth factor I regulates G2/M progression through mammalian target of rapamycin signaling in oligodendrocyte progenitors. Glia 60:1684-1695. https://doi.org/10.1002/glia.22387

44. Ye P, Li L, Richards RG et al (2002) Myelination is altered in insulin-like growth factor-I null mutant mice. J Neurosci 22:6041605120026581

45. Mason JL, Xuan S, Dragatsis I, Efstratiadis A, Goldman JE (2003) Insulin-like growth factor (IGF) signaling through type 1 IGF receptor plays an important role in remyelination. J Neurosci 23: 7710-7718

46. Zeger M, Popken G, Zhang J, Xuan S, Lu QR, Schwab MH, Nave $\mathrm{KA}$, Rowitch D et al (2007) Insulin-like growth factor type 1 receptor signaling in the cells of oligodendrocyte lineage is required for normal in vivo oligodendrocyte development and myelination. Glia 55:400-411. https://doi.org/10.1002/glia.20469

47. De Paula ML, Cui Q-L, Hossain S et al (2014) The PTEN inhibitor bisperoxovanadium enhances myelination by amplifying IGF-1 signaling in rat and human oligodendrocyte progenitors. Glia 62: 64-77. https://doi.org/10.1002/glia.22584

48. Hlavica M, Delparente A, Good A, Good N, Plattner PS, Seyedsadr MS, Schwab ME, Figlewicz DP et al (2017) Intrathecal insulin-like growth factor 1 but not insulin enhances myelin repair in young and aged rats. Neurosci Lett 648:41-46. https://doi.org/10.1016/j.neulet.2017.03.047

49. Aberg ND, Brywe KG, Isgaard J (2006) Aspects of growth hormone and insulin-like growth factor-I related to neuroprotection, regeneration, and functional plasticity in the adult brain. ScientificWorldJournal 6:53-80. https://doi.org/10.1100/tsw. 2006.22

50. O'Kusky J, Ye P (2012) Neurodevelopmental effects of insulinlike growth factor signaling. Front Neuroendocrinol 33:230-251. https://doi.org/10.1016/j.yfrne.2012.06.002

51. Janowska J, Ziemka-Nalecz M, Sypecka J (2018) The differentiation of rat oligodendroglial cells is highly influenced by the oxygen tension: in vitro model mimicking physiologically normoxic conditions. Int J Mol Sci 19:19. https://doi.org/10.3390/ ijms19020331

52. Sypecka J, Sarnowska A, Gadomska-Szabłowska I et al (2013) Differentiation of glia-committed NG2 cells: the role of factors released from hippocampus and spinal cord. Acta Neurobiol Exp (Wars) 73:116-129

53. He L, Lu QR (2013) Coordinated control of oligodendrocyte development by extrinsic and intrinsic signaling cues. Neurosci Bull 29:129-143. https://doi.org/10.1007/s12264-013-1318-y

54. Sypecka J, Sarnowska A (2013) Heterogeneity of local tissue microenvironment influences differentiation of oligodendroglial progenitors. Folia Neuropathol 51:103-110

55. Wheeler NA, Fuss B (2016) Extracellular cues influencing oligodendrocyte differentiation and (re)myelination. Exp Neurol 283: 512-530. https://doi.org/10.1016/j.expneurol.2016.03.019

56. Alagappan D, Ziegler AN, Chidambaram S, Min J, Wood TL, Levison SW (2014) Insulin-like growth factor receptor signaling is necessary for epidermal growth factor mediated proliferation of SVZ neural precursors in vitro following neonatal hypoxia-ischemia. Front Neurol 5:79. https://doi.org/10.3389/fneur.2014.00079 
57. Elitt CM, Rosenberg PA (2014) The challenge of understanding cerebral white matter injury in the premature infant. Neuroscience 276:216-238. https://doi.org/10.1016/j.neuroscience.2014.04.038

58. Newville J, Jantzie LL, Cunningham LA (2017) Embracing oligodendrocyte diversity in the context of perinatal injury. Neural Regen Res 12:1575-1585. https://doi.org/10.4103/1673-5374. 217320

59. Janowska J, Sypecka J (2018) Therapeutic strategies for leukodystrophic disorders resulting from perinatal asphyxia: focus on myelinating oligodendrocytes. Mol Neurobiol 55:43884402. https://doi.org/10.1007/s12035-017-0647-7

60. Umran RMR, Al-Tahir M, Jagdish D, Chouthai N (2016) Insulinlike growth factor-1 levels in term newborns with hypoxicischemic encephalopathy. Am J Perinatol 33:640-645. https:// doi.org/10.1055/s-0036-1571319

61. Cao Y, Gunn AJ, Bennet L, Wu D, George S, Gluckman PD, Shao XM, Guan J (2003) Insulin-like growth factor (IGF)-1 suppresses oligodendrocyte caspase- 3 activation and increases glial proliferation after ischemia in near-term fetal sheep. J Cereb Blood Flow Metab 23:739-747. https://doi.org/10.1097/01.WCB. $0000067720.12805 .6 \mathrm{~F}$

62. Wood TL, Loladze V, Altieri S, Gangoli N, Levison SW, Brywe KG, Mallard C, Hagberg H (2007) Delayed IGF-1 administration rescues oligodendrocyte progenitors from glutamate-induced cell death and hypoxic-ischemic brain damage. Dev Neurosci 29:302310. https://doi.org/10.1159/000105471

63. Zhong J, Zhao L, Du Y et al (2009) Delayed IGF-1 treatment reduced long-term hypoxia-ischemia-induced brain damage and improved behavior recovery of immature rats. Neurol Res 31: 483-489. https://doi.org/10.1179/174313208X338133

64. Lin S, Fan L-W, Rhodes PG, Cai Z (2009) Intranasal administration of IGF-1 attenuates hypoxic-ischemic brain injury in neonatal rats. Exp Neurol 217:361-370. https://doi.org/10.1016/j. expneurol.2009.03.021

65. Herrera-Marschitz M, Neira-Peña T, Rojas-Mancilla E et al (2015) Short- and long-term consequences of perinatal asphyxia: looking for neuroprotective strategies. Adv Neurobiol 10:169-198. https:// doi.org/10.1007/978-1-4939-1372-5_9

66. Sánchez Fernández I, Morales-Quezada JL, Law S, Kim P (2017) Prognostic value of brain magnetic resonance imaging in neonatal hypoxic-ischemic encephalopathy: a meta-analysis. J Child Neurol 32:1065-1073. https://doi.org/10.1177/ 0883073817726681

67. Gerner GJ, Newman EI, Burton VJ, Roman B, Cristofalo EA, Leppert M, Johnston MV, Northington FJ et al (2019) Correlation between white matter injury identified by neonatal diffusion tensor imaging and neurodevelopmental outcomes following term neonatal asphyxia and therapeutic hypothermia: an exploratory pilot study. J Child Neurol 34:556-566. https://doi. org $/ 10.1177 / 0883073819841717$

68. Liu J, Spéder P, Brand AH (2014) Control of brain development and homeostasis by local and systemic insulin signalling. Diabetes Obes Metab 16(Suppl 1):16-20. https://doi.org/10.1111/dom. 12337

69. Soto M, Cai W, Konishi M, Kahn CR (2019) Insulin signaling in the hippocampus and amygdala regulates metabolism and neurobehavior. Proc Natl Acad Sci U S A 116:6379-6384. https://doi.org/10.1073/pnas.1817391116

70. Ohlsson C, Mohan S, Sjögren K et al (2009) The role of liverderived insulin-like growth factor-I. Endocr Rev 30:494-535. https://doi.org/10.1210/er.2009-0010

71. Santi A, Genis L, Torres Aleman I (2018) A coordinated action of blood-borne and brain insulin-like growth factor I in the response to traumatic brain injury. Cereb Cortex 28:2007-2014. https://doi. org/10.1093/cercor/bhx106
72. Craig A, Ling Luo N, Beardsley DJ, Wingate-Pearse N, Walker DW, Hohimer AR, Back SA (2003) Quantitative analysis of perinatal rodent oligodendrocyte lineage progression and its correlation with human. Exp Neurol 181:231-240. https://doi.org/10. 1016/s0014-4886(03)00032-3

73. Dean JM, Moravec MD, Grafe M, Abend N, Ren J, Gong X, Volpe JJ, Jensen FE et al (2011) Strain-specific differences in perinatal rodent oligodendrocyte lineage progression and its correlation with human. Dev Neurosci 33:251-260. https://doi.org/ 10.1159/000327242

74. Barateiro A, Fernandes A (2014) Temporal oligodendrocyte lineage progression: In vitro models of proliferation, differentiation and myelination. Biochim Biophys Acta 1843:1917-1929. https:// doi.org/10.1016/j.bbamcr.2014.04.018

75. Ziemka-Nalecz M, Janowska J, Strojek L, Jaworska J, Zalewska T, Frontczak-Baniewicz M, Sypecka J (2018) Impact of neonatal hypoxia-ischaemia on oligodendrocyte survival, maturation and myelinating potential. J Cell Mol Med 22:207-222. https://doi. org $/ 10.1111 /$ jcmm.13309

76. Ziemka-Nalecz M, Jaworska J, Sypecka J, Polowy R, Filipkowski RK, Zalewska T (2017) Sodium butyrate, a histone deacetylase inhibitor, exhibits neuroprotective/neurogenic effects in a rat model of neonatal hypoxia-ischemia. Mol Neurobiol 54:5300-5318. https://doi.org/10.1007/s12035-016-0049-2

77. Rubin RD, Watson PD, Duff MC, Cohen NJ (2014) The role of the hippocampus in flexible cognition and social behavior. Front Hum Neurosci 8:742. https://doi.org/10.3389/fnhum.2014.00742

78. Goussakov I, Synowiec S, Yarnykh V, Drobyshevsky A (2019) Immediate and delayed decrease of long term potentiation and memory deficits after neonatal intermittent hypoxia. Int J Dev Neurosci 74:27-37. https://doi.org/10.1016/j.ijdevneu.2019.03. 001

79. Schiller R, IJsselstijn H, Hoskote A, White T, Verhulst F, van Heijst A, Tibboel D (2018) Memory deficits following neonatal critical illness: a common neurodevelopmental pathway. Lancet Child Adolesc Health 2:281-289. https://doi.org/10.1016/S23524642(17)30180-3

80. Xu Y, Tian Y, Tian Y, Li X, Zhao P (2016) Autophagy activation involved in hypoxic-ischemic brain injury induces cognitive and memory impairment in neonatal rats. J Neurochem 139:795-805. https://doi.org/10.1111/jnc.13851

81. Lan K-M, Tien L-T, Cai Z, Lin S, Pang Y, Tanaka S, Rhodes P, Bhatt A et al (2016) Erythropoietin ameliorates neonatal hypoxiaischemia-induced neurobehavioral deficits, neuroinflammation, and hippocampal injury in the juvenile rat. Int J Mol Sci 17:289. https://doi.org/10.3390/ijms17030289

82. Carreau A, El Hafny-Rahbi B, Matejuk A et al (2011) Why is the partial oxygen pressure of human tissues a crucial parameter? Small molecules and hypoxia. J Cell Mol Med 15:1239-1253. https://doi.org/10.1111/j.1582-4934.2011.01258.x

83. Erecińska M, Silver IA (2001) Tissue oxygen tension and brain sensitivity to hypoxia. Respir Physiol 128:263-276. https://doi. org/10.1016/s0034-5687(01)00306-1

84. Mohyeldin A, Garzón-Muvdi T, Quiñones-Hinojosa A (2010) Oxygen in stem cell biology: a critical component of the stem cell niche. Cell Stem Cell 7:150-161. https://doi.org/10.1016/j.stem. 2010.07.007

85. Guardia Clausi M, Paez PM, Campagnoni AT, Pasquini LA, Pasquini JM (2012) Intranasal administration of aTf protects and repairs the neonatal white matter after a cerebral hypoxic-ischemic event. Glia 60:1540-1554. https://doi.org/10.1002/glia.22374

86. Gao M, Monian P, Quadri N, Ramasamy R, Jiang X (2015) Glutaminolysis and transferrin regulate Ferroptosis. Mol Cell 59: 298-308. https://doi.org/10.1016/j.molcel.2015.06.011 
87. Osso LA, Chan JR (2017) Architecting the myelin landscape. Curr Opin Neurobiol 47:1-7. https://doi.org/10.1016/j.conb.2017.06. 005

88. Hughes AN, Appel B (2019) Oligodendrocytes express synaptic proteins that modulate myelin sheath formation. Nat Commun 10: 4125. https://doi.org/10.1038/s41467-019-12059-y

89. Djannatian M, Timmler S, Arends M, Luckner M, Weil MT, Alexopoulos I, Snaidero N, Schmid B et al (2019) Two adhesive systems cooperatively regulate axon ensheathment and myelin growth in the CNS. Nat Commun 10:4794. https://doi.org/10. 1038/s41467-019-12789-Z

90. Segovia KN, McClure M, Moravec M, Luo NL, Wan Y, Gong X, Riddle A, Craig A et al (2008) Arrested oligodendrocyte lineage maturation in chronic perinatal white matter injury. Ann Neurol 63:520-530. https://doi.org/10.1002/ana.21359

91. Mabbott DJ, Noseworthy M, Bouffet E, Laughlin S, Rockel C (2006) White matter growth as a mechanism of cognitive development in children. Neuroimage 33:936-946. https://doi.org/10. 1016/j.neuroimage.2006.07.024

92. Scantlebury N, Cunningham T, Dockstader C, Laughlin S, Gaetz W, Rockel C, Dickson J, Mabbott D (2014) Relations between white matter maturation and reaction time in childhood. J Int Neuropsychol Soc 20:99-112. https://doi.org/10.1017/ S1355617713001148

93. Xiao L, Ohayon D, McKenzie IA et al (2016) Rapid production of new oligodendrocytes is required in the earliest stages of motorskill learning. Nat Neurosci 19:1210-1217. https://doi.org/10. 1038/nn.4351

94. Christodoulou JA, Murtagh J, Cyr A, Perrachione TK, Chang P, Halverson K, Hook P, Yendiki A et al (2017) Relation of whitematter microstructure to reading ability and disability in beginning readers. Neuropsychology 31:508-515. https://doi.org/10.1037/ neu0000243

95. Fernandez AM, Hernandez E, Guerrero-Gomez D, MirandaVizuete A, Torres Aleman I (2018) A network of insulin peptides regulate glucose uptake by astrocytes: potential new druggable targets for brain hypometabolism. Neuropharmacology 136: 216-222. https://doi.org/10.1016/j.neuropharm.2017.08.034

96. Garwood CJ, Ratcliffe LE, Morgan SV, Simpson JE, Owens H, Vazquez-Villaseñor I, Heath PR, Romero IA et al (2015) Insulin and IGF1 signalling pathways in human astrocytes in vitro and in vivo; characterisation, subcellular localisation and modulation of the receptors. Mol Brain 8:51. https://doi.org/10.1186/s13041015-0138-6

97. Ye P, Popken GJ, Kemper A, McCarthy K, Popko B, D'Ercole AJ (2004) Astrocyte-specific overexpression of insulin-like growth factor-I promotes brain overgrowth and glial fibrillary acidic protein expression. J Neurosci Res 78:472-484. https://doi.org/10. 1002/jnr.20288

98. Okoreeh AK, Bake S, Sohrabji F (2017) Astrocyte-specific insulin-like growth factor-1 gene transfer in aging female rats improves stroke outcomes. Glia 65:1043-1058. https://doi.org/10. 1002/glia.23142

99. Michinaga S, Koyama Y (2019) Dual roles of astrocyte-derived factors in regulation of blood-brain barrier function after brain damage. Int J Mol Sci 20:20. https://doi.org/10.3390/ ijms20030571

100. Madathil SK, Carlson SW, Brelsfoard JM, Ye P, D'Ercole AJ, Saatman KE (2013) Astrocyte-specific overexpression of insulin-like growth factor-1 protects hippocampal neurons and reduces behavioral deficits following traumatic brain injury in mice. PLoS One 8:e67204. https://doi.org/10.1371/journal.pone. 0067204

101. Aberg ND, Blomstrand F, Aberg MAI et al (2003) Insulin-like growth factor-I increases astrocyte intercellular gap junctional communication and connexin43 expression in vitro. $\mathrm{J}$ Neurosci Res 74:12-22. https://doi.org/10.1002/jnr.10734

102. Pardo J, Uriarte M, Cónsole GM, Reggiani PC, Outeiro TF, Morel GR, Goya RG (2016) Insulin-like growth factor-I gene therapy increases hippocampal neurogenesis, astrocyte branching and improves spatial memory in female aging rats. Eur J Neurosci 44: 2120-2128. https://doi.org/10.1111/ejn.13278

103. Wlodarczyk A, Holtman IR, Krueger M et al (2017) A novel microglial subset plays a key role in myelinogenesis in developing brain. EMBO J 36:3292-3308. https://doi.org/10.15252/embj. 201696056

104. Staszewski O, Hagemeyer N (2019) Unique microglia expression profile in developing white matter. BMC Res Notes 12:367. https://doi.org/10.1186/s13104-019-4410-1

105. Peferoen L, Kipp M, van der Valk P, van Noort JM, Amor S (2014) Oligodendrocyte-microglia cross-talk in the central nervous system. Immunology 141:302-313. https://doi.org/10.1111/ imm. 12163

106. Rodríguez-Iglesias N, Sierra A, Valero J (2019) Rewiring of memory circuits: connecting adult newborn neurons with the help of microglia. Front Cell Dev Biol 7:24. https://doi.org/10.3389/fcell. 2019.00024

107. Kiernan EA, Wang T, Vanderplow AM, Cherukuri S, Cahill ME, Watters JJ (2019) Neonatal intermittent hypoxia induces lasting sex-specific augmentation of rat microglial cytokine expression. Front Immunol 10:1479. https://doi.org/10.3389/fimmu.2019. 01479

108. Chrzanowski U, Bhattarai S, Scheld M, Clarner T, Fallier-Becker P, Beyer C, Rohr SO, Schmitz C et al (2019) Oligodendrocyte degeneration and concomitant microglia activation directs peripheral immune cells into the forebrain. Neurochem Int 126:139-153. https://doi.org/10.1016/j.neuint.2019.03.005

109. Bilbao D, Luciani L, Johannesson B et al (2014) Insulin-like growth factor-1 stimulates regulatory $\mathrm{T}$ cells and suppresses autoimmune disease. EMBO Mol Med 6:1423-1435. https://doi.org/ 10.15252/emmm.201303376

110. Rodriguez-Perez AI, Borrajo A, Diaz-Ruiz C et al (2016) Crosstalk between insulin-like growth factor-1 and angiotensinII in dopaminergic neurons and glial cells: role in neuroinflammation and aging. Oncotarget 7:30049-30067. https://doi.org/10. 18632/oncotarget.9174

111. Labandeira-Garcia JL, Costa-Besada MA, Labandeira CM, VillarCheda B, Rodríguez-Perez AI (2017) Insulin-like growth Factor-1 and neuroinflammation. Front Aging Neurosci 9:365. https://doi. org/10.3389/fnagi.2017.00365

112. Walker DG, Lue L-F, Beach TG, Tooyama I (2019) Microglial phenotyping in neurodegenerative disease brains: Identification of reactive microglia with an antibody to variant of $\mathrm{CD} 105 /$ endoglin. Cells 8. https://doi.org/10.3390/cells8070766

113. Ziemka-Nalecz M, Jaworska J, Zalewska T (2017) Insights into the neuroinflammatory responses after neonatal hypoxia-ischemia. J Neuropathol Exp Neurol 76:644-654. https://doi.org/10. 1093/jnen/nlx046

114. Han F, Perrin RJ, Wang Q, Wang Y, Perlmutter JS, Morris JC, Benzinger TLS, Xu J (2019) Neuroinflammation and myelin status in Alzheimer's disease, Parkinson's disease, and normal aging brains: a small sample study. Parkinsons Dis 2019:79754077975412. https://doi.org/10.1155/2019/7975407

115. Viana IMMN, de Almeida MES, Lins MP, dos Santos Reis MD, de Araújo Vieira LF, Smaniotto S (2015) Combined effect of insulin-like growth factor-1 and CC chemokine ligand 2 on angiogenic events in endothelial cells. PLoS One 10:e0121249. https:// doi.org/10.1371/journal.pone.0121249

116. Hellstrom A, Ley D, Hallberg B et al (2017) IGF-1 as a drug for preterm infants: a step-wise clinical development. Curr Pharm Des 
$23: 5964-5970$. https://doi.org/10.2174/ 1381612823666171002114545

117. Thomi G, Joerger-Messerli M, Haesler V, Muri L, Surbek D, Schoeberlein A (2019) Intranasally administered exosomes from umbilical cord stem cells have preventive neuroprotective effects and contribute to functional recovery after perinatal brain injury. Cells 8:8. https://doi.org/10.3390/cells8080855

Publisher's Note Springer Nature remains neutral with regard to jurisdictional claims in published maps and institutional affiliations. 